\title{
Clarifying the zircon Hf isotope record of crust-mantle evolution
}

\author{
Jeffery D. Vervoort ${ }^{\mathrm{a}}$ and Anthony I. S. Kemp ${ }^{\mathrm{b}}$ \\ ${ }^{\mathrm{a}}$ School of the Environment, Washington State University, Pullman, WA 99163 USA \\ (vervoort@wsu.edu) \\ ${ }^{\mathrm{b}}$ School of Earth and Environment, The University of Western Australia, Crawley, WA, Australia \\ (tony.kemp@uwa.edu.au)
}




\begin{abstract}
Zircon has played a critically important role in our understanding of the growth and evolution of the Earth. The $\mathrm{U}-\mathrm{Pb}$ isotope system as preserved in zircon, more than any other mineral or method, has provided the most precise geochronological constraints for timing of geological events and processes on the Earth. More recently, technological advances have allowed for the precise determination of the Hf isotope composition of zircon, a geochemical tracer that has provided important details on the Earth's chemical evolution, in particular the evolution of the crust-mantle system. When combined, $\mathrm{U}-\mathrm{Pb}$ ages and $\mathrm{Hf}$ isotopes in zircons hold the promise of providing unprecedented resolution in the timing and processes of planetary differentiation. Nowhere is this more true than for the early history of the Earth, where younger tectonothermal processes have compromised the isotope information in bulk rock samples. With the promise of this integrated technique, however, lies numerous potential pitfalls in the acquisition and interpretation of these data. In this paper we review several important issues related to unraveling the complexities of integrated $\mathrm{U}-\mathrm{Pb}$ age and $\mathrm{Hf}$ isotope datasets, especially with respect to understanding crust-mantle evolution. In particular, we address the potential difficulty of assigning accurate initial $\mathrm{Hf}$ isotope compositions as well as some of the inherent problems associated with so-called "depleted-mantle model ages". Finally, we make some suggestions regarding the optimum analytical approach and presentation of the $\mathrm{Hf}$ (and $\mathrm{Nd}$ ) isotope data to obtain the clearest record of Earth's chemical evolution.
\end{abstract}

Keywords: hafnium isotopes, early Earth, continental crust formation, geochemical evolution, zircon, U-Pb geochronology 


\section{Introduction}

Zircon Hf isotope data have been used increasingly to constrain global models for the growth and differentiation of the continental crust (Patchett, 1983; Stevenson and Patchett, 1990; Corfu and Noble, 1992; Vervoort et al., 1996; Amelin et al., 2000; Harrison et al., 2005; Kemp et al., 2006; Belousova et al., 2010; Iizuka et al., 2010; Hawkesworth, et al., 2010; Dhuime et al., 2012; Kemp and Hawkesworth, 2013). These data, in many ways, have become the centerpiece of crustal evolutionary studies. This has been enabled largely by the advent of micro-analytical techniques that allow the rapid determination of $\mathrm{U}-\mathrm{Pb}$ age and $\mathrm{Hf}$ isotope compositions from the same zircon grain and, in some cases, even the same zircon volume (e.g., Woodhead et al., 2004, Kemp et al., 2009, 2010; Harrison et al., 2008, Yuan et al., 2008; Xie et al., 2008; KylanderClark, 2013; Fisher et al., 2014a). This is a very powerful approach that has been used to great effect not only for understanding magmatic rocks (e.g., Kemp et al., 2007; Fisher et al., 2014a) but also for looking at detrital zircons (Zeh et al., 2008; Belousova et al., 2010; Iizuka et al., 2010; Wang et al., 2009; Hawkesworth, et al., 2010; Wang et al., 2011; Dhuime et al., 2012; Iizuka et al., 2013; Zeh et al., 2014), where the geological context of the parent rock has been lost. This is of obvious importance for the Hadean Eon $(4.5-4.0 \mathrm{Ga})$, where there are no known zircon-bearing magmatic rocks, but where detrital zircons hold promise of providing critically important information about processes and conditions in the earliest Earth (e.g., Froude et al., 1983; Amelin et al., 1999; Wilde et al., 2001; Peck et al., 2001; Mojzsis et al., 2001; Valley et al., 2002, 2006; Cavosie et al., 2004, 2005; Crowley et al., 2005; Harrison et al., 2005; Watson and Harrison, 2005; Nemchin et al., 2006; Hopkins et al., 2008; Kemp et al., 2010; Trail et al., 2012).

The lure of zircon Hf isotope data for crustal evolutionary studies is, of course, the prospect of using the $\mathrm{U}-\mathrm{Pb}$ age of the zircon to place the Hf isotopic composition into a firm temporal framework-something that is essential for an accurate assessment of crust-mantle

evolution. With the explosion of published zircon $\mathrm{Hf}$ data, however, this age-isotopic relationship is often casually assumed to be correct and accurate but is not always critically 
verified. If the age information is either inaccurate, or does not correspond to the Hf isotope composition, such as where the age and Hf isotope compositions are determined on separate zircon growth domains, the resulting combination of these two will produce artefacts in the $\mathrm{Hf}$ isotope record that are a function only of this mismatch and do not inform us on the processes of crust-mantle evolution. Moreover, such age inaccuracies propagate large uncertainties into Hf model 'crust formation' or 'crustal residence' ages, from which some recent continental growth curves have been derived (e.g., Belousova et al., 2010; Wang et al., 2009; Dhuime et al., 2012). These curves are significantly different than ones based on zircon crystallization ages (e.g., Iizuka et al., 2010), and have profound implications for the timing and rate of silicate Earth differentiation.

Many tens of thousands of zircon Hf isotope analyses have now been published from the full spectrum of samples - from the oldest rocks and zircon grains to the youngest. In view of this ever-increasing database, it is timely to critically evaluate some key issues regarding the integrity of the zircon age-Hf isotope record that can potentially impede advances in our understanding of the geochemical evolution of the Earth. The purpose of this invited contribution is to address several of these key issues as follows: 1) The "age problem" - linking accurate ages to the Hf isotope compositions, including the effects of ancient $\mathrm{Pb}$ loss, a particularly vexing problem for the oldest zircons; 2) mixed analyses arising from sampling of different isotopic and age domains in zircons; and 3) the use and misuse of zircon Hf model ages.

We show that without a systematic, detail-oriented approach, which accurately integrates age and isotope compositions, analysis of zircons - particularly detrital zircons and zircons from ancient, complicated rocks - can yield meaningless isotope information that further clouds our understanding of Earth evolution. The ultimate aim of this contribution is to arrive at a more objective way to present and interpret the burgeoning age and Hf isotope data from zircons, particularly for use in reconstructing the history of crust - mantle evolution.

\section{The Age Problem}




\subsection{Background}

In order to calculate accurate initial $\mathrm{Hf}$ isotope ratios (and model ages, see below), it is imperative that we know, accurately and unambiguously, the time at which the Hf signal was first incorporated into the zircon. This requires not only a robust determination of the $\mathrm{U}-\mathrm{Pb}$ crystallization age for the grain but also, in the case of complexly zoned zircons, U-Pb age measurement of the same growth zone that has been analyzed for Hf isotope composition. It is well known that zircon is remarkably retentive of primary geochemical and isotope information (Cherniak and Watson, 2003), even through high-grade metamorphism and episodes of magmatic and sedimentary recycling. This confers a distinct advantage to zircon for age and isotope studies, particularly for the early Earth. But with this retentivity also comes potential complexity, not only for mixed age and isotope components, but also for the decoupling of the $\mathrm{U}-\mathrm{Pb}$ and the $\mathrm{Hf}$ isotope systems whereby one system (typically Lu-Hf) remains closed and the other (usually U-Pb) becomes open (e.g., Amelin et al., 2000; Gerdes and Zeh, 2009; Lenting et al. 2010).

The quality filter most often used to assess the integrity of zircon U-Pb systematics is concordance; if a zircon is concordant, it is generally assumed that the U-Pb system has remained closed and will yield an accurate crystallization age. There are circumstances, however, where a concordance filter is less effective, and this can lead to large inaccuracies in initial $\mathrm{Hf}$ isotope ratios. We explore this below with reference to figure 1.

Uranium-lead isotope disturbance in zircon generally involves loss or redistribution of radiogenic $\mathrm{Pb}$. In the case of $\mathrm{Pb}$ loss, the $\mathrm{U}-\mathrm{Pb}$ composition, when viewed today, is displaced along a chord from the true age of crystallization on the concordia curve to the age of $\mathrm{Pb}$ loss. For zero-age (present-day) $\mathrm{Pb}$ loss, this discordia line has an intercept at a $\mathrm{Pb} / \mathrm{U}$ ratio $=0$ (e.g., Fig. 1A) and thus deviates noticeably from concordia. Critically, recent $\mathrm{Pb}$ loss does not affect the ${ }^{207} \mathrm{~Pb} /{ }^{206} \mathrm{~Pb}$ age because the isotope composition of the fugitive $\mathrm{Pb}$ is the same as that

remaining within the crystal. Therefore the ${ }^{207} \mathrm{~Pb} /{ }^{206} \mathrm{~Pb}$ ratio remains a valid measure of zircon 
crystallization age, particularly in old ( $>1 \mathrm{Ga})$ zircons where it can be determined with acceptable precision by in situ techniques. In these cases, a well-determined ${ }^{207} \mathrm{~Pb} /{ }^{206} \mathrm{~Pb}$ age can be used to derive an accurate initial Hf isotope composition (Fig. 1A).

For ancient $\mathrm{U}-\mathrm{Pb}$ disturbances, however, the ${ }^{207} \mathrm{~Pb} /{ }^{206} \mathrm{~Pb}$ ratios are partially or completely reset to the ages of the thermal events that caused the Pb loss. In this case, the measured ${ }^{207} \mathrm{~Pb} /{ }^{206} \mathrm{~Pb}$ ratio will not yield an accurate crystallization age. Furthermore, depending on the age of $\mathrm{Pb}$ loss, the discordia line can be sub-parallel to concordia on Wetherill and Tera-Wasserburg diagrams (Fig. 1B). Analyses from such disturbed zircon domains thus may appear concordant or slightly discordant (especially with the higher uncertainties inherent in in-situ U-Pb analyses), making the age disturbance much more difficult to detect. Ancient Pb loss can produce a spread of ${ }^{206} \mathrm{~Pb} /{ }^{238} \mathrm{U}$ and ${ }^{207} \mathrm{~Pb} /{ }^{206} \mathrm{~Pb}$ ages within the same zircon growth domains (Fig. 1B), and be cryptic in the sense that there may be no accompanying microstructural evidence for isotope disturbance. The Hadean Jack Hills detrital zircons, for example, show this effect particularly well (see Cavosie et al., 2004; Nemchin et al., 2006). If the geological context of the host rock is unknown, as is the case for detrital zircons or inherited cores, it becomes difficult, if not impossible, to unambiguously determine the true crystallization age of the grain.

Ancient $\mathrm{Pb}$ loss produces apparent ${ }^{207} \mathrm{~Pb} /{ }^{206} \mathrm{~Pb}$ ages that are younger than the true magmatic ages, which, in turn, results in the initial Hf isotopic compositions of these zircons being calculated at the wrong age. If this $\mathrm{Pb}$ loss is unrecognized, as can be the case with Archean zircons as we demonstrate below, the effect on calculated initial epsilon Hf values can be dramatic (Fig. 1B). The reason for this is that even though the ${ }^{176} \mathrm{Hf} /{ }^{177} \mathrm{Hf}$ ratios of the zircons evolve very slowly because of their very low ${ }^{176} \mathrm{Lu} /{ }^{177} \mathrm{Hf}$ ratios $(\sim 0.001)$, the CHUR (CHondritic Uniform Reservoir) reference evolves much faster due to its much higher ${ }^{176} \mathrm{Lu} /{ }^{177} \mathrm{Hf}(0.0336$; Bouvier et al., 2008). It is this difference in the rate of evolution between zircons and CHUR that results in initial $\varepsilon_{\mathrm{Hf}}$ values for zircons being highly sensitive to the assigned age. Specifically, the zircon $\varepsilon_{\mathrm{Hf}}$ value will be anomalously low by $\sim 2.2 \varepsilon_{\mathrm{Hf}}$ units for each $0.1 \mathrm{Ga}$ the estimated age is 
too young (Fig. 1B). It is therefore essential that the zircon crystallization age be known accurately and unambiguously.

\subsection{Case studies}

Variable age resetting from ancient $\mathrm{Pb}$ loss poses a severe challenge for $\mathrm{Hf}$ isotope studies, particularly of old zircons. We show this with reference to case studies from two of the oldest terrestrial rock packages, the Acasta Gneiss Complex of Canada and the Amîtsoq Gneisses of southern West Greenland. These are classic localities that are critically important for understanding the earliest stages of crust-mantle evolution on Earth.

Guitreau et al. (2012) presented U-Pb and Hf isotope data for zircons of several samples from the Acasta Gneiss Complex. The protracted thermal and deformational history of these ancient, multi-component gneisses has been well documented, and this is borne out by the exceedingly complex growth microstructures of the constituent zircons (e.g., Bowring and Williams, 1999). Not surprisingly, and as found in other studies (Bowring and Williams, 1999; Amelin et al., 2000; Iizuka et al., 2006), Guitreau et al. (2012) report a large apparent age spread for these zircons, spanning $>1 \mathrm{Ga}$ (Fig. 2A-C). For some samples, zircon $\varepsilon_{\mathrm{Hf}}$ values, calculated at the measured $\mathrm{Pb}-\mathrm{Pb}$ age, range over 25 epsilon units, and define a steep linear trend in $\varepsilon_{\mathrm{Hf}}$ time space that extends to markedly unradiogenic values (Fig. 2C). Taken at face value, this array of data could be attributed to the continued reworking and recycling of a crustal source over the course of a billion years. When these same data are viewed more critically, however, one can see that the ${ }^{176} \mathrm{Hf} /{ }^{177} \mathrm{Hf}$ ratios of the zircons are effectively identical, irrespective of the apparent ${ }^{207} \mathrm{~Pb} /{ }^{206} \mathrm{~Pb}$ age (Fig. 2B). Moreover, the age-Hf isotope trend corresponds to a ${ }^{176} \mathrm{Lu} /{ }^{177} \mathrm{Hf}$ value that is too low $(\sim 0.001)$ to represent the evolution of a plausible source reservoir. These observations indicate that zircons of this gneiss sample have a single age and Hf isotope composition. The spread of measured ages simply reflect different degrees of ancient $\mathrm{Pb}$ loss, and not the progressive recycling of an ancient crustal source (e.g., Gerdes and Zeh, 2009). The resulting variable $\varepsilon_{\mathrm{Hf}}$ values derived using these ages are thus artefacts of incorrect age 
assignment and are not representative of the Hf isotopic composition of the magmatic source at the time of crystallization. Such data should clearly be avoided in studies seeking to unravel the chemical evolution of the Earth.

The Acasta gneiss zircons analyzed by Guitreau et al. (2012) are strongly discordant and show clear evidence for non-zero aged $\mathrm{Pb}$ loss on concordia diagrams. Such obviously disturbed zircons would not normally be targeted for Hf isotope analysis. Guitreau et al. (2012) recognized this discordance and applied a concordance filter to their data, excluding discordant analyses from their interpretations. A simple concordance filter, which is based on the comparison of ${ }^{206} \mathrm{~Pb} /{ }^{238} \mathrm{U}$ and ${ }^{207} \mathrm{~Pb} /{ }^{206} \mathrm{~Pb}$ ages, is, however, insufficient to recognize many cases of ancient $\mathrm{Pb}$ loss because of the tendency for $\mathrm{Pb}$ loss in Archean zircons to track close to Concordia (e.g., Whitehouse and Kemp, 2010; see also Fig 1B). This is shown quite clearly by the case study of the Amîtsoq Gneisses (Fig. 2D-F). Zircon grains in these rocks also have a spread of ${ }^{207} \mathrm{~Pb} /{ }^{206} \mathrm{~Pb}$ ages, but unlike the Acasta gneiss sample above, most analyses are concordant (Fig. 2D), within the error limits of SIMS analysis (Whitehouse et al., 1999). Laser ablation Hf isotope data generated from one Amîtsoq gneiss sample define a single, steep trend in $\varepsilon_{\mathrm{Hf}}$-time space to distinctly negative $\varepsilon_{\mathrm{Hf}}$ (Fig. 2F; Kemp et al., 2009). As with the Acasta gneisses, however, the Amîtsoq zircons have invariant ${ }^{176} \mathrm{Hf} /{ }^{177} \mathrm{Hf}$ over the range of apparent ${ }^{207} \mathrm{~Pb} /{ }^{206} \mathrm{~Pb}$ ages (Fig $2 \mathrm{E}$ ). This indicates that a single magmatic component is present, and that the $150 \mathrm{Ma}$ apparent age range of the Amîtsoq Gneiss zircons is a consequence of ancient $\mathrm{Pb}$ loss. The low $\varepsilon_{\mathrm{Hf}}$ values are thus meaningless, being calculated using zircon ages that are too young - a critical point that would not be evident if concordance alone was the sole criteria to assess the reliability of the measured zircon ${ }^{207} \mathrm{~Pb} /{ }^{206} \mathrm{~Pb}$ age.

Although the age disturbance in the Amîtsoq gneiss zircons is far less obvious than in the Acasta example, a clue that the U-Pb systematics are compromised lies in the variation of ${ }^{207} \mathrm{~Pb} /{ }^{206} \mathrm{~Pb}$ ages within the same growth zone of individual zircon grains (Whitehouse et al., 1999; Kemp et al., 2009). These age relationships should cast suspicion on the veracity of the low initial $\varepsilon_{\mathrm{Hf}}$ values. If such zircons were eroded into the sedimentary reservoir, however, these 
relationships will often go unrecognized and their true crystallization age would be indeterminable in the absence of geological context. As a result, the spuriously unradiogenic Hf could go unrecognized and give a false indication of the isotopic composition of the source rocks from which such a zircon was derived. For example, the low initial $\varepsilon_{\mathrm{Hf}}$ values of some detrital zircons from the Jack Hills (Western Australia) have been cited as evidence for the remelting of Hadean (>4 Ga) TTG-like, continental crust (Harrison et al., 2005; Blichert-Toft and Albarede, 2008) but an alternative explanation is that these low $\varepsilon_{\mathrm{Hf}}$ values are analytical artefacts, and result from misidentified ancient $\mathrm{Pb}$ loss (Kemp et al., 2010). In igneous samples, ancient $\mathrm{Pb}$ loss can be more easily recognized by combined $\mathrm{U}-\mathrm{Pb}$ and $\mathrm{Hf}$ isotope systematics from cogenetic grains from the same parent rock. This underlines the importance of targeting well-preserved igneous rock samples - and cautions against a reliance on detrital zircons - in crustal evolutionary studies.

\section{Mixed sampling of complex zircons}

In addition to the complications of $\mathrm{U}-\mathrm{Pb}$ isotope disturbance, another important issue is whether the U-Pb age and $\mathrm{Hf}$ isotope analyses represent measurements from discrete age/isotope domains in the zircon or represent unintentional mixtures of multiple growth zones with different crystallization ages and Hf isotope compositions. The former can yield robust age and isotopic information; the latter will produce geologically meaningless mixtures. These age and Hf isotope mixtures can happen either during total dissolution of zircons as part of solution $\mathrm{U}-\mathrm{Pb}$ and $\mathrm{Hf}$ isotope analyses or by sampling different age/isotope zones using in situ techniques.

\subsection{Mixtures produced during zircon dissolution}

One obvious case of mixed analyses is the incorporation of multiple growth zones during acid dissolution of zircon grains (Fig. 1C). There is little question that for simple zirconsformed during a single magmatic event and with homogeneous Hf isotope compositions - a method involving complete dissolution, subsequent chemistry to purify the $\mathrm{Hf}$ and Lu, and 
analysis of these purified solutions, yields the most precise and accurate Hf isotope data. However, heterogeneous zircon crystals with differing age and Hf isotope components are common in rocks that have long and complex thermal histories. These components may be younger overgrowths, inherited cores, or different growth zones in the zircon crystal, each with discrete age/isotope compositions. Strategies employed to remove or mitigate the effects of these complexities have been employed in the U-Pb zircon geochronology community for decades and include physical abrasion to remove thin rim overgrowths (e.g., Krogh, 1982), chemical abrasion to remove highly damaged Pb-loss zones (e.g., Mattinson, 2005), or analysis of zircon fragments (e.g., Benford et al., 2010). In practice, however, it is difficult to completely avoid these multiple components and heterogeneities if they are present, which is often the case for zircons from ancient rocks.

Identifying potential mixtures in zircon solution analyses can be challenging but is possible in the case of magmatic rocks. For example, in combined $\mathrm{U}-\mathrm{Pb}$ and $\mathrm{Hf}$ isotope analyses of multiple zircons or zircon fragments, as is the case in typical ID-TIMS U-Pb zircon geochronology, the $\mathrm{U}-\mathrm{Pb}$ data can be used to determine the crystallization age of the rock and the corresponding $\mathrm{Hf}$ isotope data can be then used to determine whether the zircons represent a homogeneous magmatic population or a mixed age/isotope population (e.g., Amelin et al., 2000). For example, if $\mathrm{Hf}$ isotope compositions are homogeneous but there are ${ }^{207} \mathrm{~Pb} /{ }^{206} \mathrm{~Pb}$ age variations in the population, then the Hf was incorporated during one zircon growth event and the age variations were produced during some later $\mathrm{U}-\mathrm{Pb}$ disturbance, probably $\mathrm{Pb}$ loss (e.g., as in section 2.2). If, on the other hand, there are Hf isotope compositional variations that correlate with the age of the zircon, then the Hf was incorporated into the zircon during two (or more) different growth events. For single detrital zircons, however, none of these controls can be used and, therefore, it is likely impossible to unambiguously identify these heterogeneities by solution analysis should they exist.

\subsection{Mixtures produced during in-situ techniques}


Spatially resolved in-situ $\mathrm{U}-\mathrm{Pb}$ age and $\mathrm{Hf}$ isotope analyses have been increasingly employed in an effort to circumvent these complexities. This typically involves determining the U-Pb age by either ion microprobe or by laser ablation (LA)-ICPMS and then measuring the Hf isotope composition by LA-MC-ICPMS. The Hf isotope measurement may either be performed on top of the pit resulting from $\mathrm{U}-\mathrm{Pb}$ analysis (especially where the latter was done by ion microprobe), or by ablating another part of the zircon grain that is thought to represent the same growth zone. An important point to consider, however, is that the volumes sampled during sequential $\mathrm{U}-\mathrm{Pb}$ age and Hf isotope measurements are very different. This is obviously true in the case of two different analyses by LA-ICPMS (one for $\mathrm{U}-\mathrm{Pb}$ age, the other for Hf isotope composition), but it is also the case with a U-Pb age determination by SIMS and a later overlapping Hf isotope analysis by LA-MC-ICPMS. Here, the ion microprobe samples the upper 1-2 microns of the polished zircon crystal, whereas Hf isotope data are acquired by ablating a volume several orders of magnitude greater. Complicated mixtures can, therefore, still result during analyses if the zircons preserve age and Hf isotope zonation. Although two-dimensional CL and/or BSE images provide essential information on the internal structure and zonation of zircons - and should be employed in all cases - these give no guarantee of zircon structure or zones at depth.

Strategies to minimize mixed sampling during in-situ microanalysis include concurrent Pb-Hf isotope measurement (Woodhead et al., 2004; Harrison et al., 2008; Kemp et al., 2009) or simultaneous $\mathrm{U}-\mathrm{Pb}$ and $\mathrm{Hf}$ isotope determination by laser ablation 'split streaming' (Yuan et al., 2008; Xie et al., 2008; Kylander-Clark, 2013; Fisher et al., 2014a), where age and Hf isotope data are obtained from a single ablation. Heterogeneities can still be incorporated, particularly where large (i.e., > 40 micron) spot sizes are used, but these complexities can be recognized by the changing $\mathrm{U}-\mathrm{Pb}$ or $\mathrm{Hf}$ isotopic compositions during the analyses. Under favorable (but rare) circumstances, these mixed signals can be deconvolved by selecting a homogeneous segment of the analyses. In most cases, such mixed analyses must simply be flagged for removal from the dataset. 


\subsection{Example of complexity related to mixed zircon sampling}

In our view, the example that best encapsulates the collective potential complexities of zircon Hf isotope data-and their misinterpretation - is from the Hadean ( $>4 \mathrm{Ga}$ ) Jack Hills detrital zircons. Two data sets from these zircons published by Harrison et al. (2005) and Blichert-Toft and Albarède (2008) are characterized by apparent extreme heterogeneities in initial Hf isotopic composition. These highly scattered data (e.g., "Heterogeneous Hadean Hf" of Harrison et al., 2005) were used to argue for widespread and extreme differentiation of the Earth into highly enriched and depleted reservoirs very early in its history. These Hf isotope data, however, were generated either by separate SHRIMP and LA-ICPMS with the latter using very large (up to 81 micron) laser spots (Harrison et al., 2005), or by dissolution of whole zircons (Harrison et al., 2005; Blichert-Toft and Albarede, 2008) - in spite of the well documented complex growth and disturbance history of these grains revealed by ion microprobe U-Pb studies (e.g., Compston and Pidgeon, 1978; Wilde et al., 2001; Cavosie et al., 2004, 2005; Nemchin et al., 2008). Both these techniques will likely incorporate multiple components in the zircon analyses and, importantly, will yield $\mathrm{U}-\mathrm{Pb}$ ages that are either poorly constrained or do not correspond to the measured $\mathrm{Hf}$ isotope compositions. Such complexities, collectively, will generate large variation in the age-Hf isotope record; spurious positive $\varepsilon_{\mathrm{Hf}}$ values, for example, can arise through mixed sampling and incorrect age assignment (Fig. 1C). Subsequent studies of the Jack Hills detrital zircons, utilizing concurrent $\mathrm{Pb}$ and $\mathrm{Hf}$ isotope measurements and screened for alteration and complexity on the basis of oxygen isotopes and age variations (Kemp et al., 2010), have not reproduced this heterogeneity. These latter data, and the first Jack Hills data by Amelin et al. (1999), in contrast, plot along a $\mathrm{Hf}$ isotope evolution trend that can be interpreted to represent reworking of early formed Hadean mafic crust (Kemp et al., 2010). Most notable in these data is the absence of highly radiogenic or extremely unradiogenic values present in the Harrison et al. (2005) and Blichert-Toft and Albarède (2008) datasets; in specific, there are no zircons with positive initial $\varepsilon_{\mathrm{Hf}}$ values, implying that none of these zircons were derived from a highly depleted mantle 
reservoir, in contrast to the interpretations of Harrison et al. (2005) and Blichert-Toft and Albarède (2008).

Thus, there are stark differences between the heterogeneous data of Harrison et al. (2005) and Blichert-Toft and Albarède (2008) and the subsequent concurrent analyses filtered for alteration and complexity by Kemp et al. (2010) and Harrison et al. (2008). In spite of the high potential for artefacts in the data of Harrison et al. (2005) and Blichert-Toft and Albarède (2008) due to incorrect age assignment or mixed analyses, inclusion of these data persists in databases and discussions of the Hf isotope record of the early Earth (e.g., Hoffmann et al., 2010; 2011; Belousova et al., 2010; Guitreau et al., 2012; Nebel et al., 2014). Until such heterogeneity is verified by more careful, controlled analyses, these problematic Jack Hills data should be excluded from crustal evolution models.

\section{Zircon Hf model 'crust formation' ages}

\subsection{What are model ages?}

One approach that has seen an explosion of growth in recent years-largely because of the enhanced capability to determine $\mathrm{U}-\mathrm{Pb}$ age and $\mathrm{Hf}$ isotope data on the same zircon grain-is the application of zircon Hf "depleted mantle" or "crustal residence" model ages (e.g., Griffin et al., 2002, 2004; Anderson et al., 2002; Hawkesworth and Kemp, 2006; Zheng et al., 2006; Chu et al., 2006; Nebel et al., 2007; Belousova et al., 2010; Iizuka et al, 2010; Dhuime et al., 2012). Formally, model ages represent the average time since the source(s) of the zircon's host rocks separated from the mantle. This is commonly considered to be the approximate time of addition of juvenile, mantle-derived material to the continents, a necessary requirement for constraining the growth and evolution of continental crust.

Zircon Hf model ages are calculated in much the same way as has been done for several decades using Sm-Nd isotope data from whole rocks (McCulloch and Wasserburg, 1978), but with one very important difference. In brief, Sm-Nd (and Lu-Hf) model ages of whole-rock samples use the present-day ${ }^{143} \mathrm{Nd} /{ }^{144} \mathrm{Nd}$ (and ${ }^{176} \mathrm{Hf} /{ }^{177} \mathrm{Hf}$ ) compositions to calculate the growth 
trajectory back into time using the measured ${ }^{147} \mathrm{Sm} /{ }^{144} \mathrm{Nd}$ (and ${ }^{176} \mathrm{Lu} /{ }^{177} \mathrm{Hf}$ ) in the rock until this evolution intersects a reference curve for a terrestrial reservoir. The time corresponding to that intersection is referred to as the model age. The key difference with zircon Hf model ages is that because the zircons have lower $\mathrm{Lu} / \mathrm{Hf}$ than the source rocks from which they were derived, they require two stages of modeled evolution. The 'first stage' uses the measured ${ }^{176} \mathrm{Hf} /{ }^{177} \mathrm{Hf}$, ${ }^{176} \mathrm{Lu} /{ }^{177} \mathrm{Hf}$, and $\mathrm{U}-\mathrm{Pb}$ age of the zircon to calculate the ${ }^{176} \mathrm{Hf} /{ }^{177} \mathrm{Hf}$ ratio at the time of zircon crystallization (Fig. 3A,B). From this point, the second stage must assume a ${ }^{176} \mathrm{Lu} /{ }^{177} \mathrm{Hf}$ value of the crustal source rock from which the zircon was derived to calculate the sample's evolution to the point of intersection with the terrestrial reference (Fig. 3A,B). Both chondritic (CHUR) and depleted mantle (DM) evolution curves have been used for this reference, the choice of which is generally indicated in subscript (i.e. $\mathrm{T}_{\mathrm{CHUR}}$ or $\mathrm{T}_{\mathrm{DM}}$ ).

\subsection{Model ages - the caveats}

Zircon based hafnium model ages have become the centerpiece of many crustal evolutionary studies. It must be kept in mind, however, that model ages are not true, quantifiable ages in the strict geochronologic sense, but rather derivative parameters that carry several significant inherent assumptions. These assumptions are detailed separately below and relate to: 1) the isotope composition of the mantle reservoir from which new crust was derived; 2) the $\mathrm{Lu} / \mathrm{Hf}$ ratio of the zircon host rock; and 3) the veracity of the zircon age used in the calculation. At best, uncertainties in these assumptions will introduce bias into model age distributions; at worst they can result in the model ages, and any broader inferences drawn from these, being geologically meaningless.

\subsubsection{Choice of Mantle Curve}

Most commonly, Hf model ages are calculated assuming that new crust was extracted from the 'depleted' mantle-i.e., the part of the mantle depleted in incompatible elements that has evolved with a higher $\mathrm{Lu} / \mathrm{Hf}$ ratio than that of the chondritic reference. Common depleted mantle 
formulations (e.g., Griffin et al., 2002, 2004; Anderson et al., 2002; Zheng et al., 2006; Chu et al., 2006; Nebel et al., 2007; Belousova et al., 2010; Iizuka et al, 2010; Dhuime et al., 2012) are derived by projecting the average $\mathrm{Hf}$ isotope ratio of mean, modern-day radiogenic MORB (e.g., Vervoort and Blichert-Toft, 1999; Chauvel and Blichert-Toft, 2001) back to an undifferentiated bulk Earth composition (i.e., epsilon $\mathrm{Hf}=0$ ) at the age of planetary accretion (e.g., Vervoort and Blichert-Toft, 1999). The use of Hf model ages, calculated in this way, is problematic for two main reasons as detailed below.

First, is the assumption that juvenile continental crust is derived from average depleted mantle. It is well established that MORB, as overwhelmingly the most common mantle-derived magma, has a large range of $\mathrm{Hf}$ and $\mathrm{Nd}$ isotope compositions (Salters and Hart, 1993; Vervoort et al., 1999; Chauvel and Blichert-Toft, 2001). The Hf isotope range of modern MORB exceeds $10 \varepsilon_{\mathrm{Hf}}$ units, and that of oceanic intraplate basalts is even larger (e.g., Chauvel et al., 2008). There is no unique depleted upper mantle composition from which new continental crust would be extracted at the present day, and this almost certainly applies further back in time. Dhuime et al. (2012) suggested that Hf model ages instead be calculated against a curve corresponding to the global average mantle source of island arc basalts. The average island arc curve lies at lower $\varepsilon_{\mathrm{Hf}}$ than the depleted MORB-mantle curve, reflecting recycling of older $\mathrm{Hf}$ from subducted lithosphere, and thus model ages calculated using this would be systematically younger (e.g., Fig. 3A,B). There is, however, an even larger spread in the Hf isotope composition of modern island arc magmas (e.g., Vervoort et al., 1999; Dhuime et al., 2012), due to variation in the age and nature of materials being subducted, and in the efficiency of slab-to-wedge transport of Hf (e.g., Pearce et al., 1999). The uncertainties in an island arc mantle model may, therefore, be even greater than for the MORB-source mantle model.

The second major problem is that most studies that calculate Hf model ages assume a simple linear evolution of the depleted mantle reservoir back to $\sim 4.5 \mathrm{Ga}$. Recent Hf isotope compilations of juvenile, mantle-derived compositions using the new ${ }^{176} \mathrm{Lu}$ decay constant of $1.867 * 10^{-11} \mathrm{y}^{-1}$ (Scherer et al., 2001; Söderlund et al., 2004) do not, however, show positive $\varepsilon_{\mathrm{Hf}}$ 
values prior to $3.8 \mathrm{Ga}$ (e.g., Vervoort et al., 2012, 2013). Therefore, a depleted mantle evolution reference line from modern day radiogenic $\operatorname{MORB}\left(\varepsilon_{\mathrm{Hf}} \sim+16\right)$ to $\varepsilon_{\mathrm{Hf}}=0$ at $4.5 \mathrm{Ga}$, is simply not supported by data from well-preserved mantle-derived rocks.

In summary, the choice of reference mantle source for juvenile crust will result in significant variation in calculated Hf model ages. The current common practice of referencing to a MORB-source depleted mantle curve from chondritic at $4.5 \mathrm{Ga}$ and to $\varepsilon_{\mathrm{Hf}}=+16$ today, produces a bias towards artificially old model ages.

\subsubsection{Estimation of the ${ }^{176} \mathrm{Lu} /{ }^{177} \mathrm{H} f$ of the crustal source}

Model age calculations require that the parent/daughter ratio of the magma's source rock is well constrained so that the evolution of the crustal source can be accurately extrapolated back to the reference mantle curve. In $\mathrm{Nd}$ model age calculations, as a first approximation, the source $\mathrm{Sm} / \mathrm{Nd}$ ratio is taken to be that of the analyzed whole rock. This approach has limitations for the Sm-Nd system (Arndt and Goldstein, 1987), but is even less justified for Hf model ages. This is because $\mathrm{Lu} / \mathrm{Hf}$ ratios are readily fractionated by intracrustal processes, especially those involving garnet or zircon. The Lu/Hf ratio of an igneous rock can, therefore, be significantly different from that of its crustal source. A common, somewhat arbitrary, approach for model age calculations (e.g., Griffin et al., 2002) is to adopt a source ${ }^{176} \mathrm{Lu} /{ }^{177} \mathrm{Hf}$ value typical of bulk continental crust (e.g., 0.015 as used by Griffin et al., 2002, or $\sim 0.012$, as calculated by Rudnick and Gao, 2003; see also Vervoort and Patchett, 1996 for measured ${ }^{176} \mathrm{Lu} /{ }^{177} \mathrm{Hf}$ ratios from Archean granites). In general, however, new crust from the mantle will likely be basaltic, and mafic rocks can have significantly higher - and markedly variable $-{ }^{176} \mathrm{Lu} /{ }^{177} \mathrm{Hf}$ ratios (e.g., Archean basalts from $\sim 0.02-0.03$ and potentially higher). The sensitivity of model ages to the assumed source Lu/Hf means that uncertainty in this parameter can produce inaccuracy in model ages of up to several hundred million years. This is exacerbated in young, unradiogenic zircons where the magnitude of the extrapolation back to the mantle curve is greatest (see Fig. 3A, B). 


\subsubsection{The effects of crystallization age uncertainty}

The accuracy of the measured zircon age has a profound effect on model age calculations. In the case of unrecognized ancient $\mathrm{Pb}$ loss, the calculated $\mathrm{Hf}$ model ages will be disproportionately older (see Fig. 3C) and result in the Hf isotope composition being placed in the CHUR framework with both an erroneously young age and erroneously low initial $\varepsilon_{\mathrm{Hf}}$ value. Because the model age is derived by back-calculating the Hf isotopic composition using a second stage ${ }^{176} \mathrm{Lu} /{ }^{177} \mathrm{Hf}$ ratio significantly $>0$ (e.g., 0.012 for bulk continental crust, Rudnick and Gao, 2003), the result is that the more the crystallization age is underestimated, the more the Hf model age is overestimated. This is clearly illustrated by the Acasta Hf data of Guitreau et al. (2012). Model ages calculated from the measured ${ }^{207} \mathrm{~Pb} /{ }^{206} \mathrm{~Pb}$ ages of these grains extend to values that exceed the age of the Earth. If model ages are instead calculated assuming that the original zircon crystallization age is given by the few oldest concordant U-Pb data, a sharp unimodal peak results (Fig. 4A).

Similarly, the Hf model ages for the Amîtsoq Gneiss zircons discussed above define a dual-humped distribution that ranges from $3.8 \mathrm{Ga}$ to $4.1 \mathrm{Ga}$ when calculated using the measured ages affected by $\mathrm{Pb}$ loss (Fig. 4B). These model ages exceed the oldest recognized rocks in Greenland ( 3.89 Ga, Nutman et al., 2013) by a considerable margin and are meaningless, the result of having been calculated using zircon ages that are too young. When calculated at the probable magmatic crystallization age of 3.65 Ga (Whitehouse et al., 1999), the model age spread collapses into a single sharp peak at $3.85 \mathrm{Ga}$. This corresponds to the protolith crystallization age of the oldest tonalitic gneisses in southern West Greenland (Whitehouse et al., 1999), and is consistent with the 3.65 Ga granodiorites having been derived by reworking of the older $3.85 \mathrm{Ga}$ rocks.

\subsection{The problem of mixed sources}

Arndt and Goldstein (1987) highlight the ambiguities in $\mathrm{Nd}$ model ages that can result from the melting of mixed source rocks, and these equally apply to zircon Hf model ages (see 
Fig. 3D and Kemp and Hawkesworth, 2013). Oxygen isotopes in zircon have been used to screen for hybrid model ages that arise from reworking of supracrustal material (e.g., Kemp et al., 2006), but this will not be effective in all cases (e.g., where the disparate source rocks have the same, mantle-like $\delta^{18} \mathrm{O}$ ). Mixed sources for igneous rocks may be recognized from outcrop relationships and geochemistry, but whether detrital zircons crystallized from hybrid magmas is much harder to ascertain.

\subsection{Model ages and the imperfect detrital record}

The Acasta and Amîtsoq Gneisses present dramatic examples of how Hf model ages from ancient, complicated zircons can provide a grossly inaccurate picture of crustal growth. The potential for meaningless model ages is even larger for detrital zircons, given that detecting ancient $\mathrm{Pb}$ loss is difficult, if not impossible, in the majority of in these grains (see above). Some clues to this problem might, however, be provided by studies of igneous rocks in the sediment provenance. In one example, Lancaster et al. (2011) report a U-Pb and $\mathrm{Hf}$ isotope study of detrital zircons from Cambro-Ordovician to Proterozoic metasedimentary rocks of western Scotland. These zircons have broad age peaks at ca. 1.2 Ga, 1.8 Ga and 2.5-3.0 Ga, the latter matching zircon ages in the underlying Lewisian meta-igneous gneisses, from which the sediments were, in part, derived (Whitehouse et al., 2006). The detrital zircons, however, yield a spread of Hf model ages that are consistently $\sim 600 \mathrm{Ma}$ older than the corresponding U-Pb ages and extend to $4.2 \mathrm{Ga}$. On this basis, Lancaster et al. (2011) suggest that growth of the North Atlantic Craton commenced in the Hadean, in spite of the lack of exposed basement of this age in the area. Yet, zircons of the outcropping Lewisian gneisses in the sedimentary provenance preserve evidence for a complex growth and disturbance history, primarily due to granulite facies metamorphism at $2.5 \mathrm{Ga}$, where $\mathrm{U}-\mathrm{Pb}$ age data from individual samples are smeared for several hundred million years along concordia (e.g., Whitehouse and Kemp, 2010). This raises the possibility that some of the Lewisian-aged detrital zircons analyzed by Lancaster et al. (2011) 
may have been affected by ancient $\mathrm{Pb}$ loss. In this case, the model age distributions, and some of the old model ages, in this study would be biased by inaccurate age assignment.

More broadly, we note that the observation of $\mathrm{Hf}$ model ages $>\mathrm{U}-\mathrm{Pb}$ ages in the detrital zircon record are often cited as prima facie evidence for the growth and reworking of ancient crust during Earth's early history (e.g., Griffin et al., 2006; Iizuka et al., 2009). Indeed, recent continental growth curves that indicate the existence of large volumes of stable continental crust in the early Earth (perhaps as much as $30-40 \%$ of present day volume by $3.5 \mathrm{Ga}$; Belousova et al., 2010; Dhuime et al., 2012) are underpinned by model age compilations from detrital zircons. It is important, however, to consider the possibility that the old and variable model ages in many of these zircons may have nothing to do with reworking of ancient crust, but reflect unrecognized ancient $\mathrm{Pb}$ loss, combined with the use of an inappropriate (strongly depleted) mantle source curve (section 4.2.1). Continental growth curves based on detrital zircons, and the profound implications of these curves for planetary geodynamics, should be viewed in the light of the limitations of model ages and the critical assumptions that underlie these.

\section{The isotope record of crust-mantle evolution: the way forward}

Given the potential complexities in the zircon Hf isotope record discussed in the preceding sections, what then is the best way forward? At the outset, it should be made clear that many of these complexities are not limited to the Hf isotope record in zircon. Nearly all of the surviving rocks and minerals from the early history of the Earth have been overprinted by multiple tectonothermal events and are rarely "pristine". As a result, complexities also exist in the wholerock $\mathrm{Nd}$ and $\mathrm{Hf}$ isotope records as well as in the zircon $\mathrm{U}-\mathrm{Pb}$ systematics, as detailed above.

In order to use radiogenic isotope data to understand the chemical evolution of the Earth, it is essential to have robust initial isotope compositions. In order to obtain these, two considerations are paramount-careful selection and documentation of samples, and accurate integration of age and isotope tracer information. In our view, the most robust approach involves the combination of $\mathrm{U}-\mathrm{Pb}$ age and $\mathrm{Hf}$ isotope information of zircons from well-preserved rocks 
that are unambiguously of magmatic origin, and where the geological context is well constrained. For such rocks, the U-Pb system can be used to constrain the crystallization age of the magma, thus ensuring that the $\mathrm{Hf}$ isotope data are placed in the correct chronologic framework. Conversely, this integrated approach can also take advantage of the Hf isotope data to unravel any age complexities, such as those that may result from $\mathrm{Pb}$ loss or inherited components. In concert, the $\mathrm{U}-\mathrm{Pb}$ age-Hf isotope dataset allows the identification of the Hf isotope composition of the original magma at the time of its crystallization. In this way, 'suspect' data can be identified and excluded from attempts to model petrogenetic or crustal evolutionary processes.

\subsection{Hf constraints from magmatic zircons}

We consider it important to present the $\mathrm{Hf}$ isotope data in a systematic way to demonstrate the coupled $\mathrm{U}-\mathrm{Pb}$ and $\mathrm{Hf}$ isotope systematics of the analyzed sample. In specific, this includes:

Presentation of age and Hf isotope data. Because Hf isotope data are only meaningful when placed in the proper temporal framework, the U-Pb age and $\mathrm{Hf}$ isotope data should be presented effectively together. One way to do this is to present U-Pb concordia plots alongside the Hf isotope plots. Another is to ensure that epsilon Hf-time plots are accompanied by ${ }^{176} \mathrm{Hf} /{ }^{177} \mathrm{Hf}$ versus time diagrams, which utilize the Hf isotope data to facilitate the identification

of $\mathrm{Pb}$ loss trends. Along with these, it is necessary to include the full $\mathrm{U}-\mathrm{Pb}$ and $\mathrm{Hf}$ isotope data in appendix tables in order to demonstrate the technical quality of $\mathrm{Hf}$ isotope measurements. These tables should include relevant $\mathrm{Hf}$ isotope ratios as well as $\mathrm{Lu} / \mathrm{Hf}$ and $\mathrm{Yb} / \mathrm{Hf}$ isotope ratios of samples and appropriate reference zircons following the recommendations of Fisher et al. (2014b).

Cathodoluminescence (CL) images. High resolution CL images should be provided for all grains analyzed along with spot locations to show potential grain complexities (inherited cores, recrystallized domains or younger overgrowths) - accepting the limitation that such images do not provide information about grain structure at depth. This is less important for zircon 
populations with simple age and Hf isotope systematics, but is of paramount importance for samples that have excessive scatter in age or Hf isotope composition.

Ages and data interpretation. An important take-away message from this paper is that, for igneous samples, Hf isotope data should be plotted at the best-determined magmatic crystallization age inferred from a zircon $\mathrm{U}-\mathrm{Pb}$ dataset, not at the apparent age of an individual $\mathrm{U}-\mathrm{Pb}$ measurement. The exception to this is when separate age components (inherited cores or younger overgrowths) can be identified and resolved. In this case, the age and Hf isotope data need to be carefully assessed. This is because the different age components will have different Hf isotope compositions, and inadvertently incorporating these into the analyses can induce artificial variations in the measured Hf isotope compositions (section 3).

ID-MC-ICMPS zircon Hf analysis. Although it is essential to be vigilant for the presence of multiple growth zones during zircon $\mathrm{U}-\mathrm{Pb}$ and $\mathrm{Hf}$ isotope analysis, for simple zircons with a single age and Hf isotope composition, the most robust approach may be through whole-grain (or grain fragment) dissolution. This would involve CA-ID-TIMS, for the most precise and accurate $\mathrm{U}-\mathrm{Pb}$ age determination, and ID-MC-ICPMS for the most precise and accurate measurement of the isotope composition of Hf isolated from the same solution (e.g., Amelin et al., 1999; 2000; Bauer et al., 2014). Reconnaissance in situ analysis and microstructural imaging could be employed to guide the selection of these 'best' zircon grains for high precision analysis.

\subsection{Evaluating existing Hf isotope data}

There are a few important points that should be considered when evaluating existing zircon Hf isotope data sets. First, it is important to evaluate the technical quality of the Hf analyses. Hf isotope data of relevant secondary $\mathrm{Hf}$ standards (i.e., those with comparable $\mathrm{Yb} / \mathrm{Hf}$ and $\mathrm{Lu} / \mathrm{Hf}$ to that of the unknown zircons) should be provided and these should have an external reproducibility (2 SD) of $\sim 1.5 \varepsilon_{\mathrm{Hf}}$ units or better, commensurate with internal precision. If the external reproducibility of the zircon standards is significantly higher than this, or if the measured ${ }^{176} \mathrm{Hf} /{ }^{177} \mathrm{Hf}$ values deviate substantially from their accepted values (determined by 
solution MC-ICPMS analysis), it may signal a problem with the analyses. Second, large variations in ${ }^{176} \mathrm{Hf} /{ }^{177} \mathrm{Hf}$ from magmatic zircon populations of the same age from the same rock must be viewed with caution. In principle, such variations can arise through geological processes - for example, zircon crystallizing from a magma undergoing open system evolution involving assimilation of older crust or mixing with a magma of contrasting isotope composition. In this case, however, zircon ${ }^{176} \mathrm{Hf} /{ }^{177} \mathrm{Hf}$ would be expected to correlate with other geochemical indices such as oxygen isotope compositions (e.g., Kemp et al., 2007) or trace element signatures. Zircons that crystallized from homogeneous, well-mixed magmas should normally have an external reproducibility ( $2 \mathrm{SD}$ ) of $\sim 2 \varepsilon_{\mathrm{Hf}}$ units or better. If the external reproducibility is significantly worse than $2 \varepsilon_{\mathrm{Hf}}$ units, this could signal the inadvertent incorporation of multiple

components (inherited cores or younger overgrowths) or a problem with the technical quality zircon Hf isotope analyses. If the higher variability coincides with high $\mathrm{Yb} / \mathrm{Hf}$, analytical problems must be suspected. If the variability correlates with the presence of inheritance or overgrowths in the zircon population, incorporation of these during the analyses is a likely cause. Recommendations for the full reporting of zircon Hf isotope data produced by LA-MC-ICPMS are given in Fisher et al., 2014b.

\subsection{Detrital zircons, whole-rock isotope data, and model ages}

The Hf isotope record from detrital zircons. For detrital zircons, the task in identifying robust and meaningful isotope data is considerably more challenging, particularly given the difficulties associated with determining accurate crystallization ages from these isolated grains (section 2). At a minimum we advocate the use of zircon quality filters to identify those grains that are least likely to have had their isotope information compromised. Nemchin et al., (2006) suggest a variety of criteria to recognize the 'least disturbed' Jack Hills detrital zircons, such as preservation of igneous microstructures (sharp oscillatory and sector zoning), multiple concordant and identical ${ }^{207} \mathrm{~Pb} /{ }^{206} \mathrm{~Pb}$ ages across the grain, a restricted range of $\mathrm{Th} / \mathrm{U}$ ratios $(0.4$ 0.8) and consistent intra-grain oxygen isotope composition. To this may be added igneous REE 
patterns (Cavosie et al., 2004) and consistent ${ }^{207} \mathrm{~Pb} /{ }^{206} \mathrm{~Pb}$ depth profiles (Kemp et al., 2010). More generally, for detrital zircon studies, users should beware of far-reaching conclusions not supported by other lines of geological evidence-especially where large Hf isotope heterogeneity is claimed and criteria for assessing data reliability have not been applied. We suggest that, when possible, there needs to be a greater attempt to ground truth the U-Pb and $\mathrm{Hf}$ isotope data against that available from the exposed igneous basement to assess whether the detrital record is truly robust and meaningful.

Whole-rock $H f$ and $N d$ isotope data. It is appropriate in this context to also consider whole-rock $\mathrm{Hf}$ and $\mathrm{Nd}$ isotope data, since this continues to feature at the center of debates over early Earth evolution (e.g., Bowring and Housh, 1995; Vervoort et al., 1996; Moorbath et al., 1997; Vervoort and Blichert-Toft, 1999; Hofmann et al., 2010, 2011; Nebel et al., 2014). The task in assessing the reliability of such data from rocks of complex terranes is notoriously difficult due to the potential presence of multiple cryptic components on the hand-sample scale. These may be difficult to recognize, particularly in poly-metamorphic layered-gneisses that are common in the early Archean, where intense deformation can blend different lithological components at the grain scale (e.g., Kinny and Nutman, 1999). The whole-rock Hf isotope data can be assessed by comparison with the zircon Hf; if both are homogenous and agree, the wholerock Hf data are probably reliable. For $\mathrm{Nd}$, the task is more difficult, because of the lack of an robust accessory phase-like zircon for $\mathrm{Hf}$ - that can provide an age-isotope check on the whole rock system. Some authors have argued for closed system isotopic behavior based on trace element behavior (e.g., Hoffmann et al., 2010, 2011) or simple U-Pb systematics (e.g., Bennett et al., 1993) but how these relate to closed system behavior in the $\mathrm{Sm}-\mathrm{Nd}$ isotope system remains uncertain. Bennett (2003) argued that the consistent $\mathrm{Nd}$ isotope compositions in suites of gneisses such as from southern West Greenland demonstrate that Sm-Nd disturbance of these rocks has been minimal. It is becoming increasingly apparent, however, that the $\mathrm{Nd}$ budget is controlled primarily by accessory phases such as monazite, allanite, titanite, and apatite that are more easily altered and isotopically equilibrated (Hammerli et al., 2014; Bauer et al., 2015). The 
behavior of the $\mathrm{Sm}-\mathrm{Nd}$ isotope system in these phases during high-grade metamorphic events is not yet clear but can potentially play a major role in the Sm-Nd isotope systematics of the corresponding whole rock.

Zircon Hf model ages. Finally, the utility of zircon Hf model ages is severely limited by the multiple, unconstrained assumptions and uncertainties that go into their calculation (section 4). It is essential for the zircon Hf practitioner to recognize that Hf model ages are not ages at all, but model-based estimates with only the most qualitative of information-they are especially problematic for zircons derived from old, complex terranes that may have been subjected to ancient episodes of $\mathrm{Pb}$ loss. A better approach, in our view, is to present the Hf isotope information with the best possible age information and avoid the use of zircon Hf model ages, or, at the very least, interpret Hf model ages in a qualitative, general sense that the geological data support.

\section{Concluding remarks}

In sum, the selective, integrated approach recommended above entails a very cautious application of Hf isotopes in crust-mantle evolution studies. We suggest that this is justified, simply because the indiscriminant use of Hf isotope data from zircons for which the true age cannot be accurately determined-either due to complex $\mathrm{Pb} / \mathrm{U}$ isotope disturbance and/or because the context of the rock has been lost-adds much ambiguity to the Hf isotopic record. Complex statistical modeling based on inadequately screened datasets, no matter how large, (e.g., Belousova et al., 2010; Guitreau et al., 2012) will only exacerbate the issue and cannot lead to geologically meaningful conclusions. Another key aspect of the suggested approach must be the realization that not all rock samples, or zircons, yield useful, unambiguous results - care in analytical practices must be matched by judicious sample selection in order to obtain the clearest picture of crust-mantle evolution. Less, in this case, is more.

Hf isotope studies of zircon have provided unique insights into Earth evolution, and we predict further exciting discoveries-particularly with continuing rapid improvement in 
analytical instrumentation, and with refinements in approach. This is particularly true with reference to the "difficult" but formative period of Earth's history (i.e., the Hadean and Eoarchean), where zircon may be the main or sole repository of isotope information about crustmantle processes. In our view, however, when examined with a critical lens, much of the claimed large Hf isotope variations in this period disappear. What we are left with, instead, is an isotopic record characterized by limited variability in ${ }^{176} \mathrm{Hf} /{ }^{177} \mathrm{Hf}$, consistent with recycling of some limited early formed crust (e.g., Amelin et al., 2000; Iizuka et al., 2009; Kemp et al., 2010; Bauer et al., 2014). Lacking are significantly positive epsilon Hf values prior to $3.8 \mathrm{Ga}$ (Vervoort et al., 2012; 2013), indicating neither widespread depletion of the mantle nor extraction of large volumes of evolved crustal material prior to $3.8 \mathrm{Ga}$. To further unravel details of early Earth evolution, the challenge will be in recognizing which ancient rocks and minerals best preserve a robust and meaningful record of crust-mantle differentiation. Careful screening of geological relationships and integration of multiple geochemical and isotope datasets are essential first steps towards this objective. In our view, taking a detailed and systematic approach to the age and Hf isotope data for all samples-especially those from the early Earth-will greatly refine the Hf isotope record of Earth's chemical evolution.

\section{Acknowledgements}

We would like to thank Timothy Horscroft and Klaus Mezger for inviting us to write this

paper. This paper was presented in various forms at meetings since 2012 and we thank many colleagues for meaningful discussions. In particular, we thank Chris Fisher for discussions about, and comments on, this manuscript. We would also like to thank the constructive comments from 3 anonymous reviewers. This work was supported in part by NSF grant EAR1321998 to Vervoort and ARC grant FT100100059 to TK. 


\section{List of Figures}

Figure 1. Schematic representation of the effects of zircon age complexity on the calculation of initial ${ }^{176} \mathrm{Hf} /{ }^{177} \mathrm{Hf}$ and $\varepsilon_{\mathrm{Hf}}(\mathrm{t})$, showing generalized evolutionary trajectories for the mantle (M), crust (C) and zircon (Z). For the latter, the asterisk at the intersection with the y axis denotes the measured (i.e., present day) zircon Hf isotope composition, and the arrow shows the back calculation of this to the chosen $\mathrm{U}-\mathrm{Pb}$ age. Three scenarios are shown, depicting $(\mathrm{A})$ recent $\mathrm{Pb}$ loss, (B) ancient $\mathrm{Pb}$ loss, and (C) a simplified case of mixed sampling of a zircon core and rim of different age and Hf isotope composition, where the initial ${ }^{176} \mathrm{Hf} /{ }^{177} \mathrm{Hf}$ and $\varepsilon_{\mathrm{Hf}}(\mathrm{t})$ values are then erroneously calculated at the age of the core. Modified from Amelin et al. (2000) and Kemp and Hawkesworth (2013).

Figure 2. U-Pb and $\mathrm{Hf}$ isotope data for zircons of rocks from the Acasta Gneiss Complex (A, B, C; data from sample AG09-008gt of Guitreau et al. 2012) and Amîtsoq Gneiss Complex (D, E, F; data from sample 125540 of Whitehouse et al. 1999). In the Acasta Gneiss example, the data were obtained as separate measurements by LA-ICPMS (U-Pb) and LA-MC-ICPMS (Hf) (Guitreau et al., 2012), whereas for the Amîtsoq Gneiss the U-Pb ages were measured by SIMS (Whitehouse et al., 1999) and Hf isotopes by LA-MC-ICPMS (Kemp et al., 2009). The dashed grey arrows depict the trends that would result from $\mathrm{Pb}$ loss from a population of co-genetic zircons with the same original crystallization age and Hf isotope composition as the oldest zircon group in each sample. These $\mathrm{Pb}$ loss trends were calculated using the average ${ }^{176} \mathrm{Lu} /{ }^{177} \mathrm{Hf}$ values for zircons of each sample (ca. 0.0011 for AG09-008gt and 0.0005 for 125540).

Figure 3. The calculation of depleted mantle model ages from Hf isotopes in zircon, also showing some of their inherent sources of uncertainty. Panels A and B show the derivation of model ages assuming that the zircon crystallized from either melts of mafic crust (' $\mathrm{T}_{\mathrm{DM}(\mathrm{MC})}$ mafic', dark green line) or bulk continental (andesitic) crust $\left(\mathrm{T}_{\mathrm{DM}(\mathrm{BC})}\right.$, light green line). For the 
case shown, the shift in model ages calculated using these different sources is about 600 million years. This emphasizes the large inaccuracies that can result if the crustal source of the zircon is unconstrained, as with detrital zircons. Panel $\mathrm{C}$ highlights the effect of ancient $\mathrm{Pb}$ loss on model ages. Here an age underestimated by $500 \mathrm{Ma}$ translates into a model age (assuming a mafic crustal source) that is 650 million years older. Panel D pertains to the case where the zircon crystallized from a hybrid magma formed by mixing between a juvenile magma and older crust. Here, the model age might not correspond to an actual geological event.

Figure 4. Probability density plots (constructed using Isoplot, Ludwig, 2001) of Hf model ages derived from the data presented in Figure 2, where these were calculated using either the ${ }^{207} \mathrm{~Pb} /{ }^{206} \mathrm{~Pb}$ ages measured from each individual zircon (blue curve) or the 'correct' age determined from the $\mathrm{U}-\mathrm{Pb}$ systematics of the entire population (red curve). The distribution of measured ${ }^{207} \mathrm{~Pb} /{ }^{206} \mathrm{~Pb}$ ages is shown for comparison (green). Model ages were calculated assuming a mafic crustal source and a mantle curve of chondritic composition. 


\section{References Cited:}

Amelin, Y., Lee, D.-C., Halliday, A.N., 2000. Early-middle Archaean crustal evolution deduced from $\mathrm{Lu}-\mathrm{Hf}$ and $\mathrm{U}-\mathrm{Pb}$ isotopic studies of single zircon grains. Geochimica et Cosmochimica Acta, 64: 4205-4225.

Amelin, Y., Lee, D.-C., Halliday, A.N., Pidgeon, R.T., 1999. Nature of the Earth's earliest crust from hafnium isotopes in single detrital zircons. Nature, 399: 252-255.

Andersen, T., Griffin, W.L., Pearson, N.J., 2002. Crustal evolution in the SW part of the Baltic Shield: the Hf isotope evidence. J. Petrology, 43: 1725-1747.

Arndt, N.T., Goldstein, S.J., 1987. Use and abuse of crust-formation ages. Geology, 15: 893-895.

Bauer, A., Bowring, S.A., Vervoort, J.D., Fisher, C.M., 2014. An integrated analytical approach to obtaining reliable $\mathrm{U}-\mathrm{Pb}$ and $\mathrm{Hf}$ isotopic data from complex ( $>3.9$ to $>3.3 \mathrm{Ga}$ ) zircon from the Acasta Gneiss Complex, AGU Fall Meeting, San Francisco, pp. V31A-4723.

Bauer, A., Fisher, C.M., Vervoort, J.D., Bowring, S.A., 2015. The Role of Accessory Phases in the Sm-Nd Isotope Systematics of the Acasta Gneiss Complex, AGU Fall Meeting, San Francisco, pp. V43D-07.

Belousova, E.A., Kostitsyn, Y.A., Griffin, W.L., Begg, G.C., O 'Reilly, S.Y., Pearson, N.J., 2010. The growth of the continental crust: Constraints from zircon Hf-isotope data. Lithos, 119: 457-466.

Benford, B., Crowley, J., Schmitz , M., C.J., N., Tikoff, B., 2010. Mesozoic magmatism and deformation in the northern Owhyee Mountains, Idaho: Implications for along- zone variations for the western Idaho shear zone. Lithosphere 2: 93-118.

Bennett, V.C., 2003. Compositional Evolution of the Mantle. In: Carlson, R.L. (Ed.), Treatise on Geochemistry. Elsevier, pp. 493-519.

Bennett, V.C., Nutman, A.P., McCulloch, M.T., 1993. Nd isotopic evidence for transient, highly depleted mantle reservoirs in the early history of the Earth. Earth Planet Sci. Lett., 119: 299317.

Blichert-Toft, J., Albarede, F., 2008. Hafnium isotopes in Jack Hills zircons and formation of the Hadean crust. Earth Planet. Sci. Lett., 265: 686-702.

Bouvier, A., Vervoort, J.D., Patchett, P.J., 2008. The Lu-Hf and Sm-Nd isotopic composition of CHUR: constraints from unequilibrated chondrites and implications for the bulk composition of terrestrial planets. Earth and Planetary Science Letters, 273(1-2): 48-57.

Bowring, S.A., Housh, T., 1995. The Earth's Early Evolution. Science, 269: 1535-1540.

Bowring, S.A., Williams, I.S., 1999. Priscoan (4.00-4.03 Ga) orthogneisses from northwestern Canada. Contrib. Mineral. Petrol., 134: 3-16.

Cavosie, A.J., Valley, J.W., Wilde, S.A., 2005. Magmatic $\delta 180$ in 4400-3900 Ma detrital zircons: a record of the alteration and recycling of crust in the Early Archaean. Earth Planet. Sci. Lett., 235: 663-681.

Cavosie, A.J., Wilde, S.A., Liu, D., Weiblen, P.W., Valley, J.W., 2004. Internal zoning and U- 
Th- $\mathrm{Pb}$ chemistry of Jack Hills detrital zircons: a mineral record of early Archaean to Mesoproterozoic (4348-1576 Ma) magmatism. Precambrian Res., 135: 251-279.

Chauvel, C., Blichert-Toft, J., 2001. A hafnium isotope and trace element perspective on melting of the depleted mantle. Earth Planet. Sci. Lett., 190: 137-151.

Chauvel, C., Lewin, E., Carpentier, M., Arndt, N.T., Marini, J.-C., 2008. Role of recycled oceanic basalt and sediment in generating the Hf-Nd mantle array. Nature Geosci., 1: 64-67.

Cherniak, D.J., Watson, E.B., 2003. Diffusion in Zircon. In: Hanchar, J.M., Hoskin, P.W.O.

(Eds.), Zircon. Reviews in Mineralogy and Geochemistry. Mineralogical Society of America and the Geochemical Society, pp. 113-143.

Chu, M.-F., Chung S.-L., Song, B., Li, D., O 'Reilly, S.Y., Pearson, N.J., Ji, J., Wen, D.J., 2006. Zircon $\mathrm{U}-\mathrm{Pb}$ and $\mathrm{Hf}$ isotope constraints on the Mesozoic tectonics and crustal evolution of southern Tibet. Geology, 34: 745-748.

Compston, W., Pidgeon, R.T., 1986. Jack Hills, evidence of more very old detrital zircons in Western Australia. Nature, 321(766-769).

Corfu, F., Noble, S.R., 1992. Genesis of the southern Abitibi greenstone belt, Superior Province, Canada: Evidence from zircon $\mathrm{Hf}$ isotope analyses using a single filament technique. Geochim Cosmochim Acta, 56: 2081-2097.

Crowley, J.L., Myers, J.S., Sylvester, P.J., Cox, R.A., 2005. Detrital zircon from the Jack Hills and Mount Narryer, Western Australia: evidence for diverse $>4.0$ Ga source rocks. Journal of Geology, 113: 239-263.

Dhuime, B., Hawkesworth, C., Cawood, P., Storey, C., 2012. A change in the geodynamics of continental growth 3 billion years ago. Science, 335: 1334-1336.

Fisher, C.M., Vervoort, J., DuFrane, A., 2014a. Accurate Hf isotope determinations of complex zircons using the "laser ablation split stream" method. Geochem. Geophys. Geosyst., 15: 121-139.

Fisher, C.M., Vervoort, J., Hanchar, J.M., 2014b. Guidelines for reporting zircon Hf isotopic data by LA-MC-ICPMS and potential pitfalls in the interpretation of these data. Chem. Geol., 363: 125-133.

Froude, F.O. Ireland, T.R., Kinny, P.D., Williams, I.S., Compston, W., Williams, I.R., Myers, J.S., 1983. Ion microprobe identification of 4,100-4,200 Myr-old terrestrial zircons. Nature, 304: 616-618.

Gerdes, A., Zeh, A., 2009. Zircon formation versus zircon alteration - New insights from combined $\mathrm{U}-\mathrm{Pb}$ and $\mathrm{Lu}-\mathrm{Hf}$ in-situ LA-ICP-MS analyses, and consequences for the interpretation of Archean zircon from the Central Zone of the Limpopo Belt. Chemical Geology, 261: 230-243.

Griffin, W.L., Belousova, E.A., Shee, S.R., Pearson, N.J., O'Reilly, S.Y., 2004. Archean crustal evolution in the northern Yilgarn Craton: $\mathrm{U}-\mathrm{Pb}$ and Hf-isotope evidence from detrital zircons. Precambrian Research 131: 231-282.

Griffin, W.L., Belousova, E.A., Walters, S.G., O'Reilly, S.Y., 2006. Archaean and Proterozoic 
crustal evolution in the Eastern Succession of the Mt Isa district, Australia: U-Pb and Hfisotope studies of detrital zircons. Aust. J. Earth Sci., 53: 125-149.

Griffin, W.L. Wang, X., Jackson, S.E., Pearson, N.J., O'Reilly, S.Y., Xu, X., Zhou, X., 2002. Zircon chemistry and magma mixing, SE China: In-situ analysis of Hf isotopes, Tonglu and Pingtan igneous complexes. Lithos 61: 237-269.

Guitreau, M., Blichert-Toft, J., Martin, H., Mojzsis, S.J., Albarede, F., 2012. Hafnium isotope evidence from Archean granitic rocks for deep mantle origin of continental crust. Earth Planet. Sci. Lett., 337-338: 211-223.

Hammerli, J., Kemp, A.I.S., Spandler, C., 2014. Neodymium isotope equilibration during crustal metamorphism revealed by in situ microanalysis of REE-rich accessory minerals. Earth Planet. Sci. Lett., 392: 133-142.

Harrison, T.M. ,Blichert-Toft, J., Muller, W., Albarede, F., Holden, P., Mojzsi, S.J., 2005. Heterogeneous Hadean hafnium: evidence of continental crust at 4.4 to $4.5 \mathrm{Ga}$. Science, 310 : 1947-1950.

Harrison, T.M., Manning, C.E., 2008. Low heat flow inferred from $>4$ Ga zircons suggests Hadean plate boundary interactions. Nature 456: 493-496.

Harrison, T.M., Schmitt, A.K., McCulloch, M.T., Lovera, O.M., 2008. Early (4.5 Ga) formation of terrestrial crust: Lu-Hf, d180, and Ti thermometry results for Hadean zircons. Earth Planet. Sci. Lett., 268: 476-486.

Hawkesworth, C.J., Dhuime, B., Pietranik, A.B., Cawood, P., Kemp, A.I.S., Storey, C.D., 2010. The generation and evolution of the continental crust. J. Geol. Soc. London, 167: 229-248.

Hawkesworth, C.J., Kemp, A.I.S., 2006. Using hafnium and oxygen isotopes in zircons to unravel the record of crustal evolution. Chemical Geology, 226(3-4): 144-162.

Hiess, J., Bennett, V.C., Nutman, A.P., Williams, I.S., 2009. In situ U-Pb, O and Hf isotopic compositions of zircon and olivine from Eoarchean rocks, West Greenland: new insights into making old crust. Geochim. Cosmochim. Acta, 73: 4489-4516.

Hoffmann, J.E., Münker C, Polat A, König S, Mezger K, Rosing M., 2010. Highly depleted Hadean mantle reservoirs in the sources of early Archean arc-like rocks, Isua supracrustal belt, southern West Greenland. Geochim. Comsochim. Acta, 74: 7236-7260.

Hoffmann, J.E., Münker, C., Polat, A., Rosing, M., Schulz, T., 2011. The origin of decoupled $\mathrm{Hf}-\mathrm{Nd}$ isotope compositions in Eoarchean rocks from southern West Greenland. Geochim. Comsochim. Acta, 75: 6610-6628.

Hopkins, M., Harrison, T.M., Manning, C.E., 2008. Low heat flow inferred from $>4$ Ga zircons suggests Hadean plate boundary interactions. Nature, 456: 493-496.

Iizuka, T., Campbell I.H., Allen C.M., Gill J.B., Maruyama S., Makoka F., 2013. Evolution of the African continental crust as recorded by $\mathrm{U}-\mathrm{Pb}, \mathrm{Lu}-\mathrm{Hf}$ and $\mathrm{O}$ isotopes in detrital zircons from modern rivers. Geochim. Comsochim. Acta, 107: 96-120.

Iizuka, T., Horie K., Komiya T., Maruyama S., Hirata T., et al., 2006. 4.2 Ga zircon xenocryst in an Acasta gneiss from northwestern Canada: Evidence for early continental crust. Geology, 
34: $245-248$.

Iizuka, T., Komiya T., Johnson S.P., Kon Y, Maruyama S, Hirata T. 2009. Reworking of Hadean crust in the Acasta gneisses, northwestern Canada: evidence from in situ Lu-Hf isotope analysis of zircon. 259: 230-239.

Iizuka, T., Komiya, T., Rino, S., Maruyama, S., Hirata, T., 2010. Detrital zircon evidence for Hf isotopic evolution of granitoid crust and continental growth. Geochim. Comsochim. Acta, 74: 2450-2472.

Kemp, A.I.S., Hawkesworth, C.J., Foster, G.L., Paterson, B.A., Woodhead, J.D., Hergt, J.M., Gray, C.M., Whitehouse, M.J., 2007. Magmatic and crustal differentiation history of granitic rocks from hafnium and oxygen isotopes in zircon. Science, 315: 980-983.

Kemp, A.I.S., Hawkesworth, C.J., Paterson, B.A., Kinny, P., 2006. Episodic growth of the Gondwana Supercontinent from hafnium and oxygen isotopes in zircon. Nature, 439(580583).

Kemp, A.I.S., Foster G.L., Schersten A., Whitehouse M.J., Darling J., Storey C., 2009. Concurrent $\mathrm{Pb}-\mathrm{Hf}$ isotope analysis of zircon by laser ablation multi-collector ICP-MS, with implications for the crustal evolution of Greenland and the Himalayas. Chemical Geology, 261: 244-260.

Kemp, A.I.S., Hawkesworth, C.J., 2013. Growth and differentiation of the continental crust from isotope studies of accessory minerals. In: Rudnick, R.L. (Ed.), Treatise On Geochemistry (2nd edition), Volume 12 The Crust. Elsevier Science, Oxford.

Kemp, A.I.S., Wilde, S.A., Hawkesworth, C. J., Coath, C.D. , Nemchin, A., Pidgeon, R. T., Vervoort, J. D., DuFrane, S. A.2010. Hadean crustal evolution revisited: New constraints from $\mathrm{Pb}-\mathrm{Hf}$ isotope systematics of the Jack Hills zircons. Earth Planet. Sci. Lett., 296: 4556.

Kinny, P.D., Nutman, A.P., 1996. Zirconology of the Meeberrie gneiss, Yilgarn Craton, Western Australia: an early Archean migmatite. Precambrian Res., 78: 165-178.

Krogh, T.E., 1982. Improved accuracy of U-Pb zircon ages by the creation of more concordant systems using an air abrasion technique. Geochimica et Cosmochimica Acta, 46: 637-649.

Kylander-Clark, A.R.C., Hacker, B.R., Cottle, J.M., 2013. Laser-ablation split-stream ICP petrochronology. Chem. Geol., 345: 99-112.

Lancaster, P.J., Storey, C.D., Hawkesworth, C.J., Dhuime, B., Understanding the roles of crustal growth and preservation in the detrital zircon record. Earth Planet. Sci. Lett., 305: 405-412.

Lenting, C., Geisler T., Gerdes A., Kooijman E., Scherer E., Zeh A., 2010, The behavior of the Hf isotope system in radiation-damaged zircon during experimental hydrothermal alteration. Am. Mineral., 95: 1343-1348.

Ludwig, K.R., 2001. Isoplot/Ex Rev. 2.49. Berkeley Geochronology Centre, Special Publication 1 a.

Mattinson, J.M., 2005. Zircon U-Pb chemical abrasion (CA-TIMS) method: Combined annealing and multi-step partial dissolution analysis for improved precision and accuracy of 
zircon ages. Chem. Geol., 220: 47-66.

McCulloch, M.T., Wasserburg, G.J., 1978. Sm-Nd and Rb-Sr chronology of continental crust formation. Science, 200: 1003-1011.

Mojzsis, S.J., Harrison, T.M., Pidgeon, R.T., 2001. Oxygen-isotope evidence from ancient zircons for liquid water at the Earth's surface 4,300 Myr ago. Nature, 409: 178-181.

Moorbath, S., Whitehouse, M.J., Kamber, B.S., 1997. Extreme Nd-isotope heterogeneity in the early Archean - fact or fiction? Case histories from northern Canada and west Greenland. Chemical Geology, 135: 213-231.

Nebel, O., Campbell, I.H., Sossi, P.A., Van Kranendonk, M.J., 2014. Hafnium and iron isotopes in early Archean komatiites record a plume-driven convection cycle in the Hadean Earth. Earth Planet. Sci. Lett., 397: 111-120.

Nebel, O., Nebel-Jacobsen, Y., Mezger, K., Berndt, J., 2007. Initial Hf isotope compositions in magmatic zircon from early Proterozoic rocks from the Gawler Craton, Australia: a test for zircon model ages. Chem. Geol., 241: 23-37.

Nemchin, A., Pidgeon, R.T., Whitehouse, M.J., Vaughan, J.P., Meyer, C., 2008. A light carbon reservoir recorded in zircon-hosted diamond from the Jack Hills. Nature, 454: 92-95.

Nemchin, A.A., Pidgeon, R.T., Whitehouse, M.J., 2006. Re-evaluation of the origin and evolution of $>4.2 \mathrm{Ga}$ zircons from the Jack Hills metasedimentary rocks. Earth Planet. Sci. Lett., 244: 218-233.

Nutman, A.P., Bennett, V.C., Friend, C.R.L., Hidaka, H., Yi, K., Lee, S.R., Kamiichi, T. 2013. The Itsaq Gneiss Complex of Greenland: Episodic 3900 to 3660 Ma juvenile crust formation and recycling in the 3660 to 3600 Ma Isukasian orogeny. American Journal of Science, 313: 877-911.

Patchett, P.J., 1983. Importance of the Lu-Hf isotope system in studies of planetary chronology and chemical evolution. Geochim. Cosmochim. Acta, 47: 81-91.

Pearce, J.A., Kempton, P.D., Nowell, G.M., Noble, S.R., 1999. Hf-Nd element and isotope perspective on the nature and provenance of mantle and subduction components in western Pacific arc-basin systems. Journal of Petrology, 40: 1579-1611.

Peck, W.H., Valley, J.W., Wilde, S.A., Graham, C.M., 2001. Oxygen isotope ratios and rare earth elements in 3.3 to $4.4 \mathrm{Ga}$ zircons: Ion microprobe evidence for high del180 continental crust and oceans in the Early Archean. Geochim Cosmochim. Acta., 65: 4215-4229.

Rudnick, R.L., Gao, S., 2003. Composition of the Continental Crust. In: Rudnick, R.L. (Ed.), The Crust Volume 3 Treatise on Geochemistry. Treatise on Geochemistry. Pergamon, Oxford, pp. 1-64.

Salters, V.J.M., Hart, S.R., 1991. The mantle sources of ocean ridges, islands and arcs: the Hfisotope connection. Earth and Planetary Science Letters, 104: 364-380.

Scherer, E., Münker, C., Mezger, K., 2001. Calibration of the lutetium-hafnium clock. Science, 293: 683-686.

Söderlund, U., Patchett, P.J., Vervoort, J.D., Isachsen, C.E., 2004. The 176Lu decay constant 
determined by $\mathrm{Lu}-\mathrm{Hf}$ and $\mathrm{U}-\mathrm{Pb}$ isotope systematics of Precambrian mafic intrusions. Earth and Planetary Science Letters, 219: 311-324.

Stevenson, R.K., Patchett, P.J., 1990. Implications for the evolution of contintental crust from Hf isotope systematics of Archean detrital zircons. GCA, 54: 1683-1697.

Trail, D., Watson, E.B., Tailby, N.D., 2012. Ce and Eu anomalies in zircon as proxies for the oxidation state of magmas. Geochim Cosmochim. Acta, 97: 70-87.

Valley, J.W., Cavosie, A.J., Fu, B., Peck, W.H., Wilde, S.A., 2006. Comment on 'Heterogeneous Hadean Hafnium: evidence of continental crust at 4.4 to $4.5 \mathrm{Ga}$ '. Science, 312: 1139.

Valley, J.W., Peck, W.H., King, E.M., Wilde, S.A., 2002. A cool early Earth. Geology, 30: 351354.

Vervoort, J., Fisher, C.M., Kemp, A., 2013. The myth of a highly heterogeneous Hf-Nd Eoarchean mantle and large early crustal volumes, Annual Goldschmidt Conference, Florence, Italy.

Vervoort, J., Kemp, A.I.S., Fisher, C.M., 2012. No significant production of continental crust prior to $3.8 \mathrm{Ga}$. EOS Trans. AGU, Fall Mtg. Suppl., 93.

Vervoort, J.D., Blichert-Toft, J., 1999. Evolution of the depleted mantle: Hf isotope evidence from juvenile rocks through time. Geochim. Cosmochim. Acta, 63: 533-556.

Vervoort, J.D., Blichert-Toft, J., Patchett, P.J., Albarède, F., 1999. Relationships between Lu-Hf and Sm-Nd isotopic systems in the global sedimentary system. Earth Planet. Sci. Lett., 168: 79-99.

Vervoort, J.D., Patchett, P.J., 1996. Behavior of hafnium and neodymium isotopes in the crust: constraints from Precambrian crustally derived granites. Geochim. Cosmochim. Acta, 60(19): 3717-3733.

Wang, C.Y., Campbell, I.H., Allen, C.M., Williams, I.S., Eggins, S.M., 2009. Rate of growth of the preserved North American continental crust: evidence from $\mathrm{Hf}$ and $\mathrm{O}$ isotopes in Mississippi detrital zircons. Geochimica et Cosmochimica Acta, 73: 712-728.

Wang, C.Y., Campbell, I.H., Stepanov, A.S., Allen, C.M., Burtsev, I.N., 2011. Growth rate of the preserved continental crust: constraints from $\mathrm{Hf}$ and $\mathrm{O}$ isotopes in detrital zircons from Greater Russian Rivers. Geochimica et Cosmochimica Acta, 75: 1308-1345.

Watson, E.B., Harrison, T.M., 2005. Zircon thermometer reveals minimum melting conditions on earliest Earth. Science, 308: 841-844.

Whitehouse, M.J., Bridgewater, D., Park, R.G., 1997. Detrital zircon ages from the Loch Maree Group, Lewisian Complex, NW Scotland: confirmation of a Palaeoproterozoic LaurentiaFennoscandia connection. Terra Nova, 9: 260-263.

Whitehouse, M.J., Kamber, B.S., Moorbath, S., 1999. Age significance of U-Th-Pb zircon data from early Archean rocks of west Greenland - a reassessment based on combined ion microprobe and imaging studies. Chem. Geol., 160: 201-224.

Whitehouse, M.J., Kemp, A.I.S., 2010. On the difficulty of assigning crustal residence, magmatic protolith and metamorphic ages to Lewisian granulites: constraints from combined 
in situ U-Pb and Lu-Hf. In: Law, R.D., Butler, R.W.H., Holdsworth, R.E., Krabbendam, M., Strachan, R.A. (Eds.), Continental Tectonics and Mountain Building: the Legacy of Peach and Horne. Geological Society, London, London, pp. 79-99.

Wilde, S.A., Valley, J.W., Peck, W.H., Graham, C.M., 2001. Evidence from detrital zircons for the existence of continental crust and oceans on the Earth 4.4 Gyr ago. Nature, 409: 175-178.

Woodhead, J.D., Hergt, J.M., Shelley, M., Eggins, S., Kemp, R., 2004. Zircon Hf-isotope analysis with an excimer laser, depth profiling, ablation of complex geometries, and concomitant age estimation. Chemical Geology, 209: 121-135.

Xie, L.W., Zhang, Y.B., Zhang, H.H., Sun, J.F., Wu, F.Y., 2008. In situ simultaneous determination of trace elements, $\mathrm{U} / \mathrm{Pb}$ and $\mathrm{Lu} / \mathrm{Hf}$ isotopes in zircon and baddeleyite. Chinese Sci. Bull., 53: 1565-1573.

Yuan, H.-L. et al., 2008. Simultaneous determinations of $\mathrm{U}-\mathrm{Pb}$ age, $\mathrm{Hf}$ isotopes and trace element compositions of zircon by excimer laser-ablation quadrupole and multiple-collector ICP-MS. Chemical Geology, 247: 100-118.

Zeh, A., Gerdes, A., Klemd, R., Barton Jr., J.M., 2008. U-Pb and Lu-Hf isotope record of detrital zircon grains from the Limpopo Belt - evidence for crustal recycling at the Hadean to early Archean transition. Geochimica et Cosmochimica Acta, 72: 5304-5329.

Zeh, A., Stern, R., Gerdes, A., 2014. The oldest zircons of Africa-Their U-Pb-Hf-O isotope and trace element systematics, and implications for Hadean to Archean crust-mantle evolution. Precambrian Research, 241: 203-230.

Zheng, J. et al., 2006. Widespread Archean basement beneath the Yangtze craton. Geology, 34: 417-420. 


\section{FIGURES \\ Recent Pb loss}
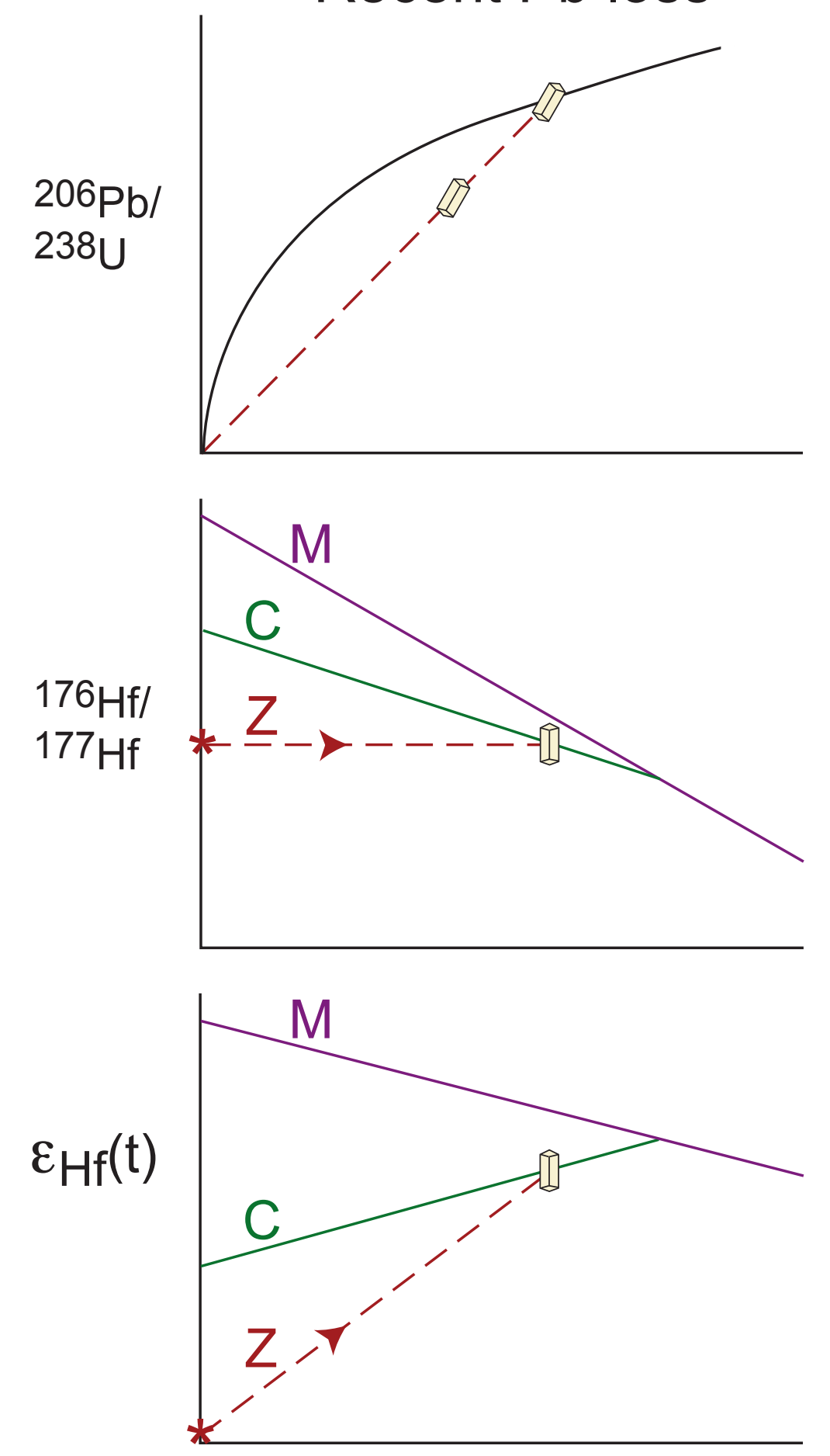

A
Ancient $\mathrm{Pb}$ loss
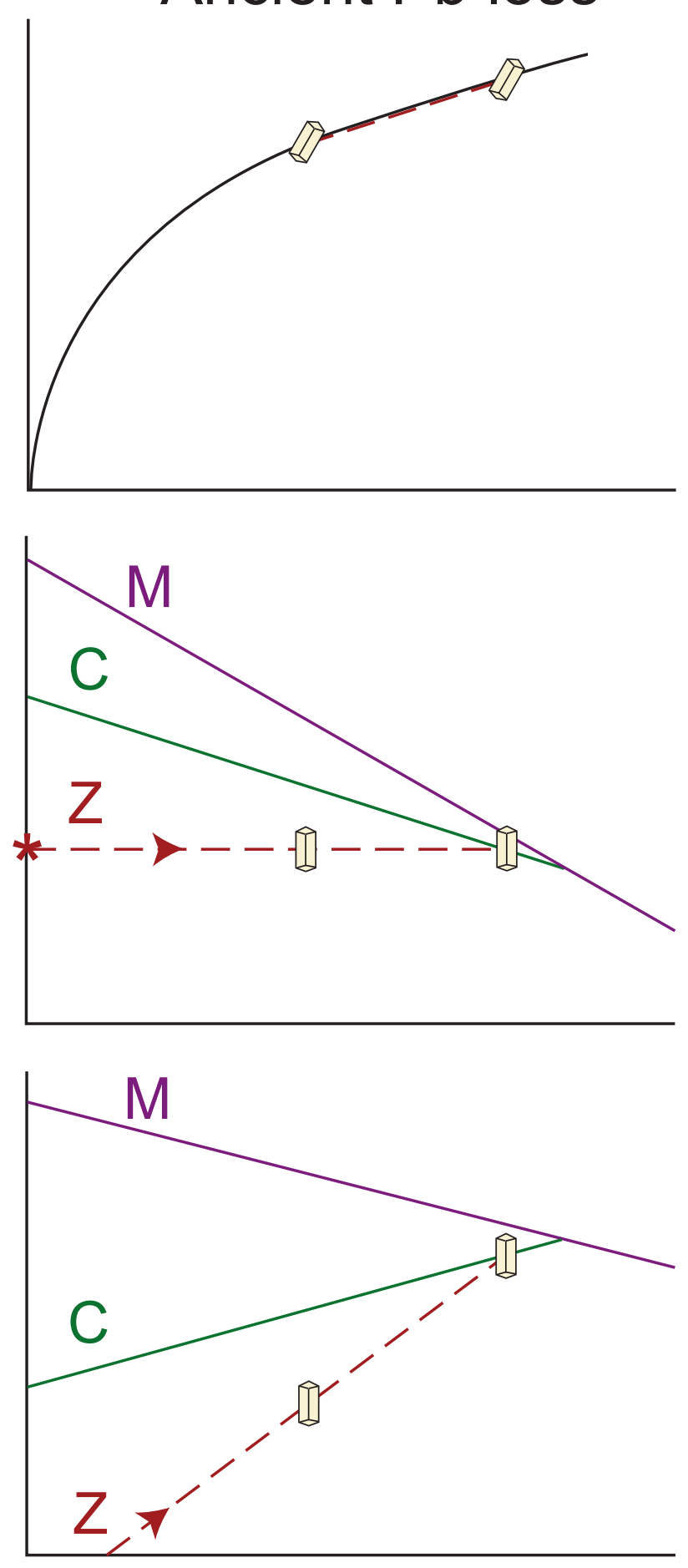

B
Multiple growth / mixed sampling
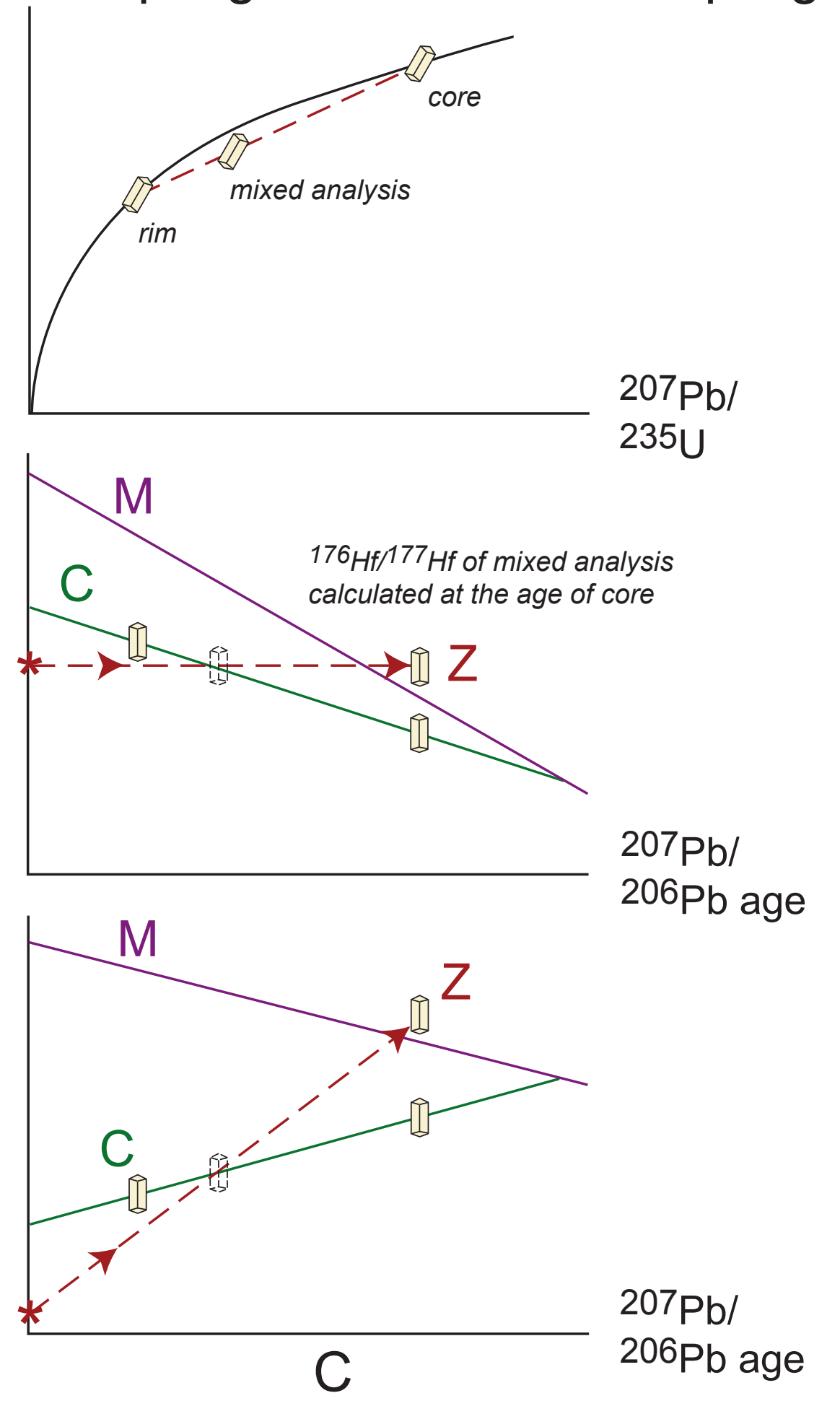

Figure 1 
Acasta Gneiss AG09-008gt
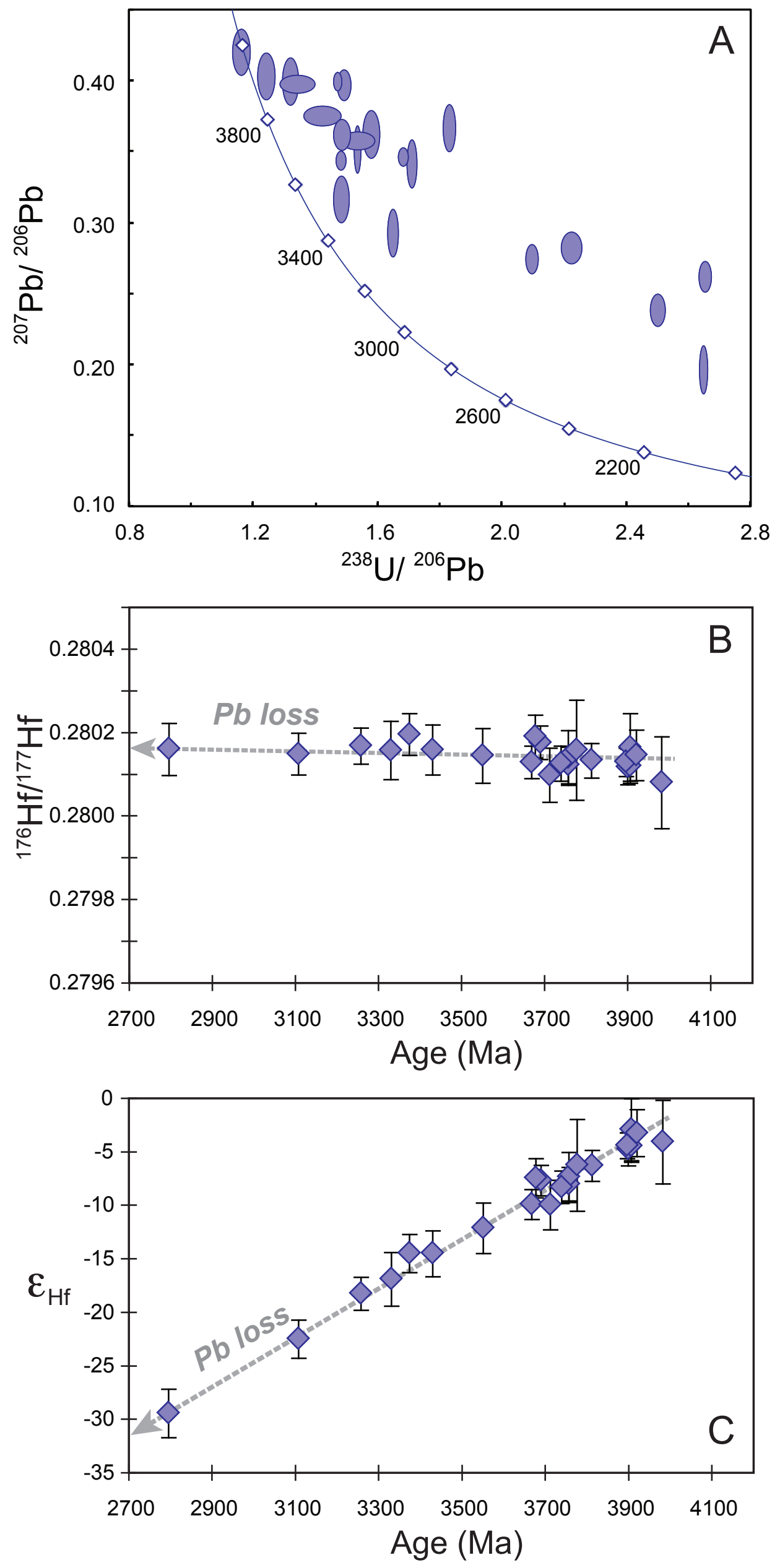

Figure $2(A, B, C)$ 


\section{Amîtsoq Gneiss 125540}
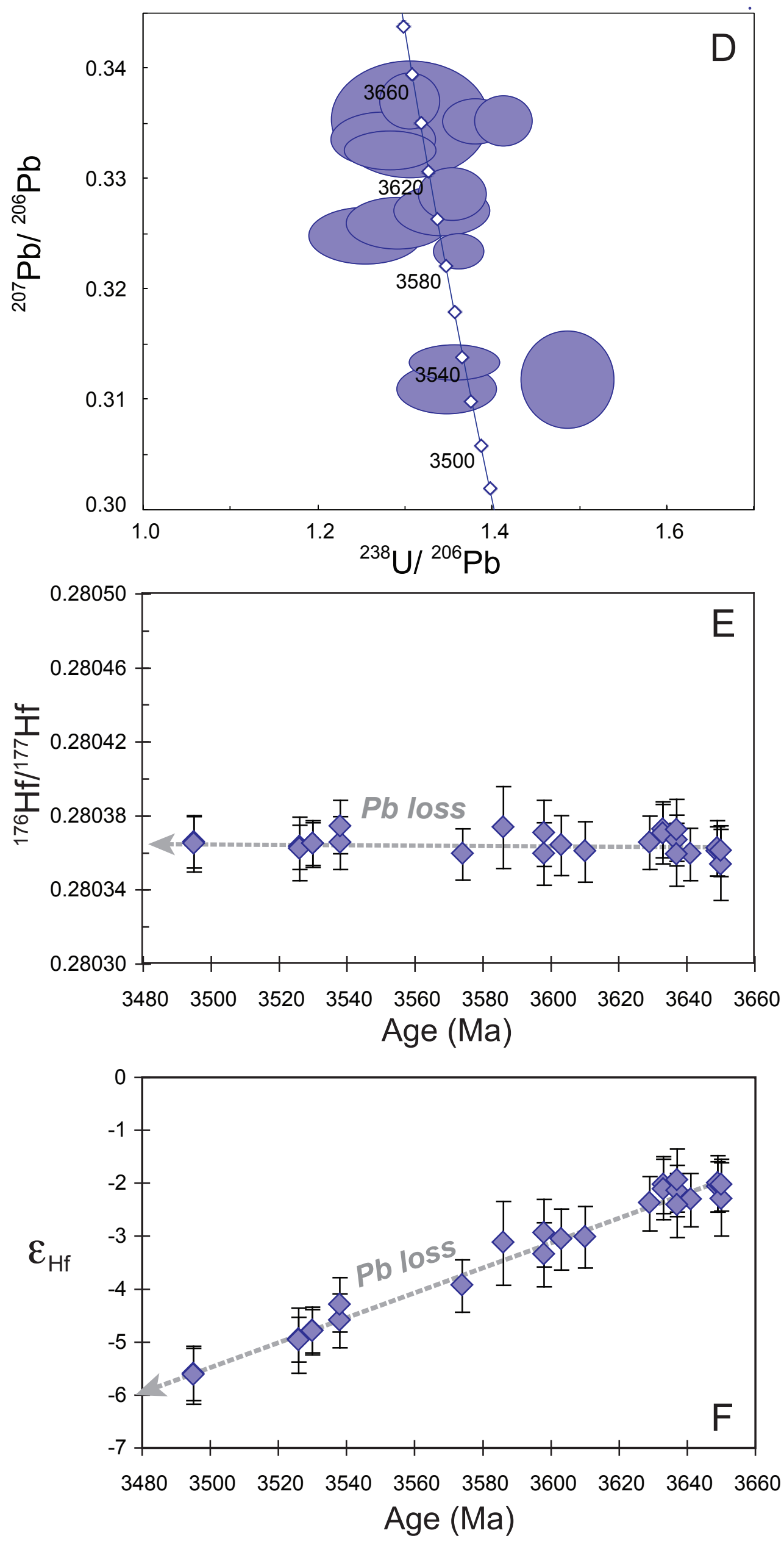

Figure $2(\mathrm{D}, \mathrm{E}, \mathrm{F})$ 

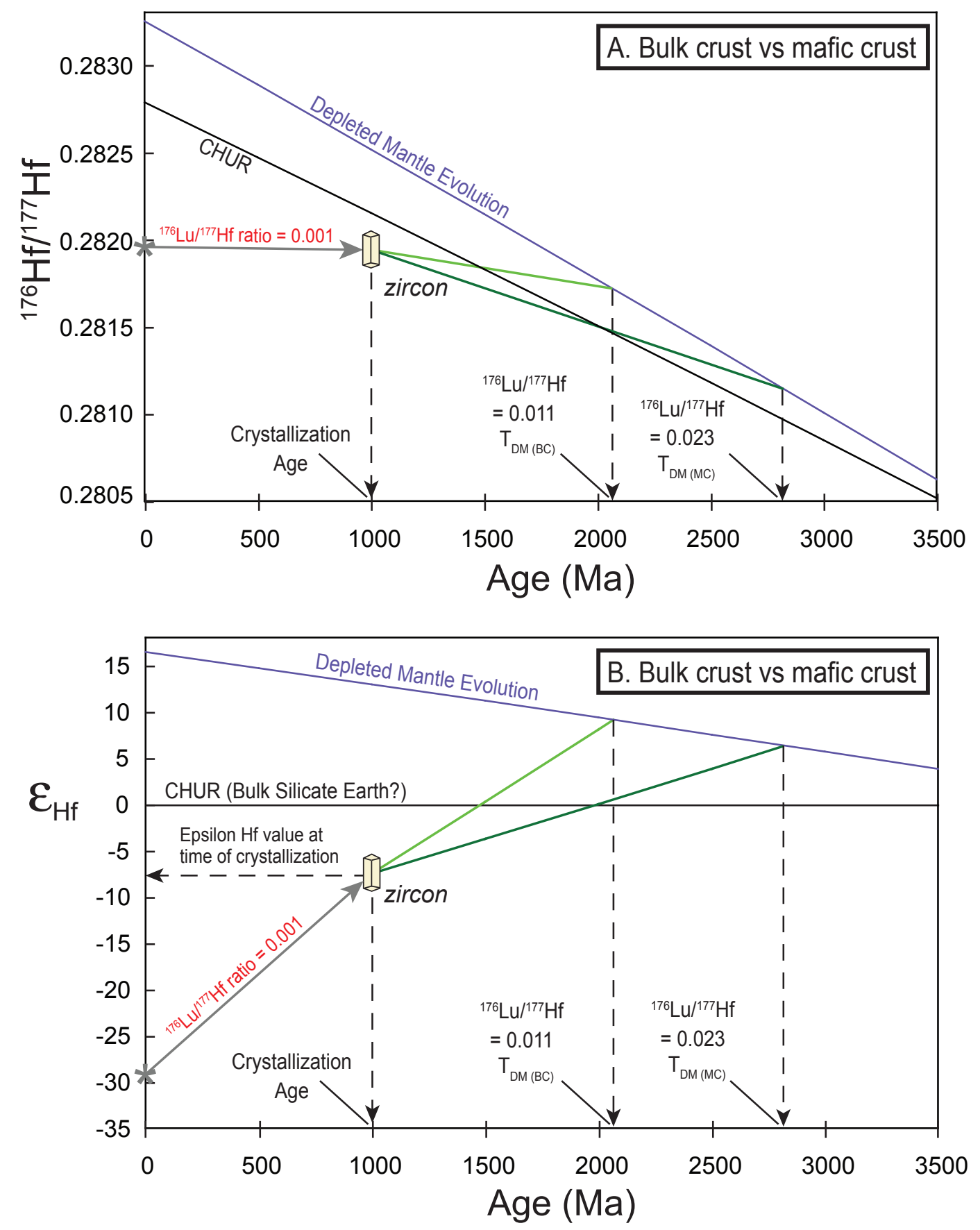

Figure $3(A, B)$ 

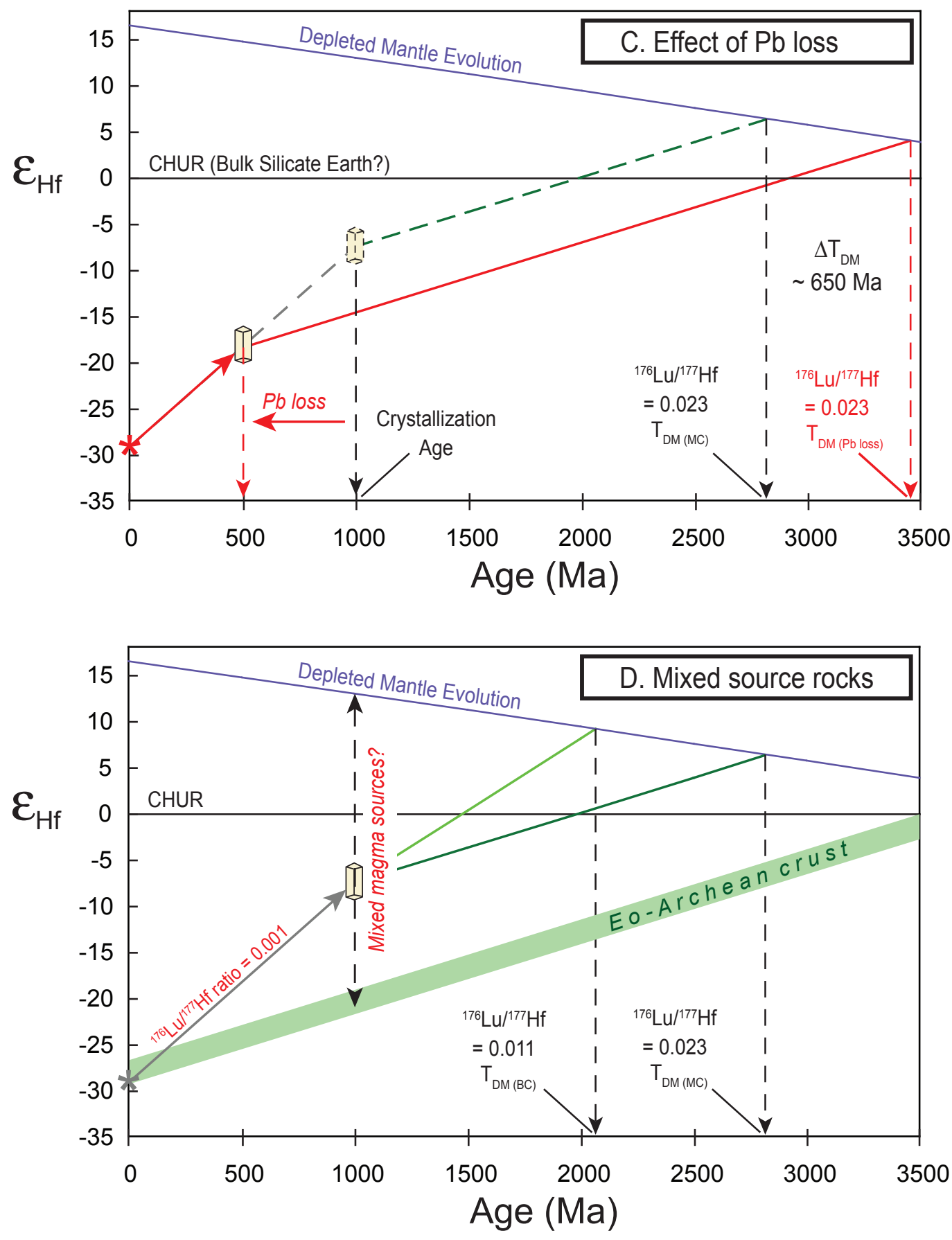

Figure $3(C, D)$ 

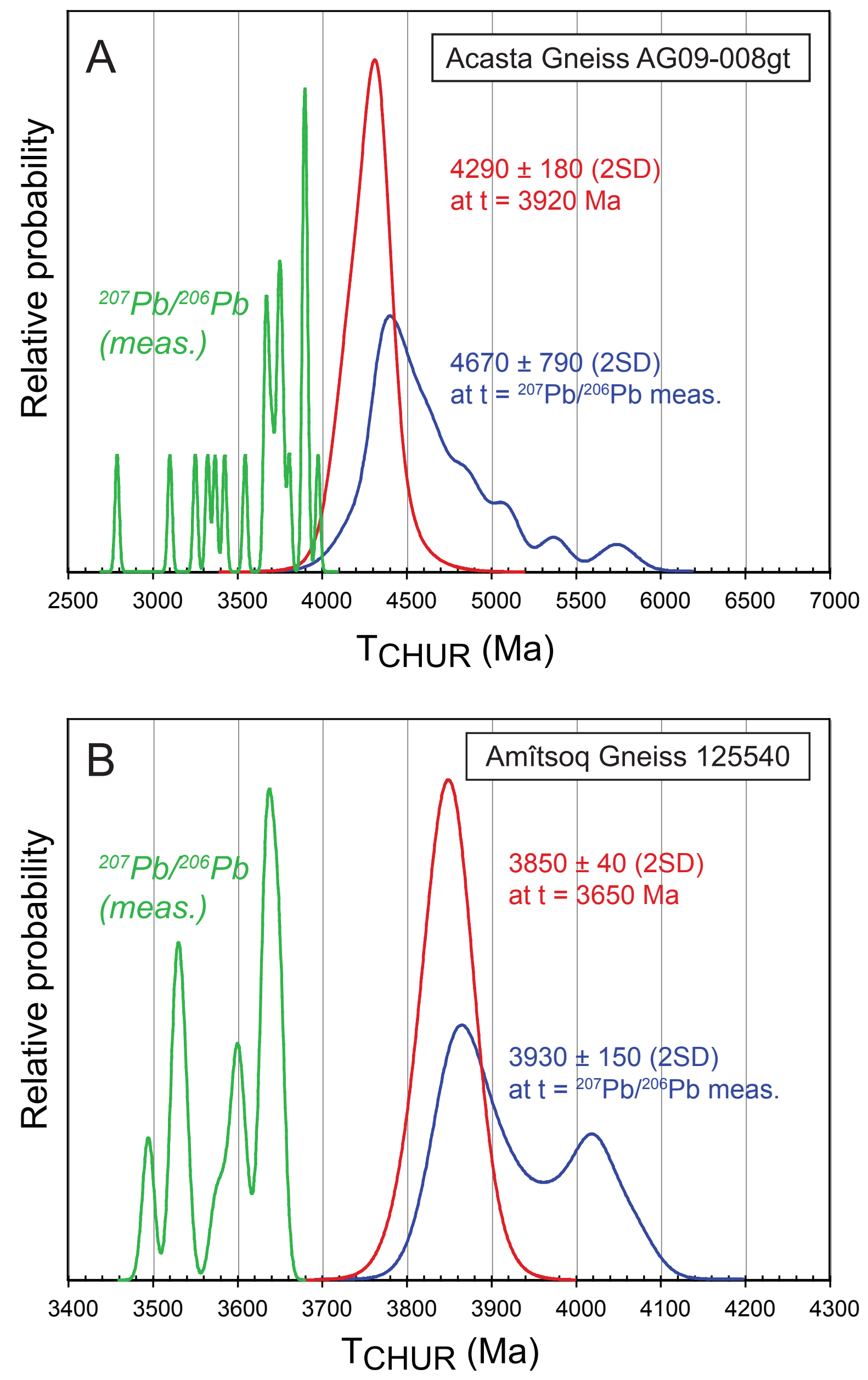

Figure 4 